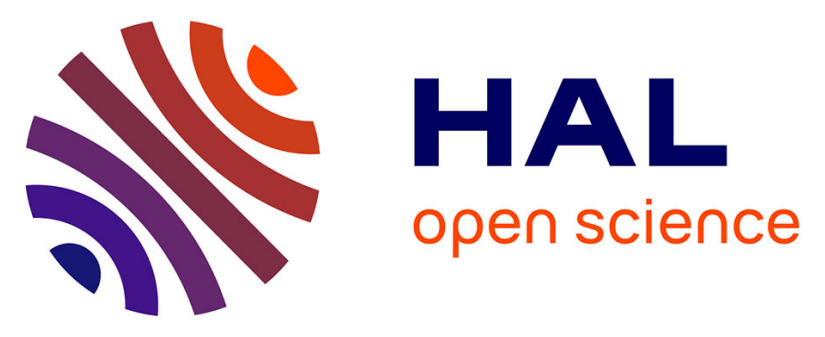

\title{
Fluid circulation pattern inside La Soufrière volcano (Guadeloupe) inferred from combined electrical resistivity tomography, self-potential, soil temperature and diffuse degassing measurements
}

\author{
Élodie Brothelande, Anthony Finizola, Aline Peltier, Eric Delcher, \\ Jean-Christophe Komorowski, Fabio Di Gangi, G. Borgogno, M. Passarella, C. \\ Trovato, Y. Legendre
}

\section{- To cite this version:}

Élodie Brothelande, Anthony Finizola, Aline Peltier, Eric Delcher, Jean-Christophe Komorowski, et al.. Fluid circulation pattern inside La Soufrière volcano (Guadeloupe) inferred from combined electrical resistivity tomography, self-potential, soil temperature and diffuse degassing measurements. Journal of Volcanology and Geothermal Research, 2014, 288, pp.105 - 122. 10.1016/j.jvolgeores.2014.10.007 . hal-01391280

\section{HAL Id: hal-01391280 \\ https: / hal.univ-reunion.fr/hal-01391280}

Submitted on 3 Nov 2016

HAL is a multi-disciplinary open access archive for the deposit and dissemination of scientific research documents, whether they are published or not. The documents may come from teaching and research institutions in France or abroad, or from public or private research centers.
L'archive ouverte pluridisciplinaire HAL, est destinée au dépôt et à la diffusion de documents scientifiques de niveau recherche, publiés ou non, émanant des établissements d'enseignement et de recherche français ou étrangers, des laboratoires publics ou privés. 


\title{
Fluid circulation pattern inside La Soufrière volcano (Guadeloupe) inferred from combined electrical resistivity tomography, self-potential, soil temperature and diffuse degassing measurements
}

\author{
E. Brothelande ${ }^{\mathrm{a}, *}$, A. Finizola ${ }^{\mathrm{a}}$, A. Peltier ${ }^{\mathrm{b}}$, E. Delcher ${ }^{\mathrm{a}}$, J.-C. Komorowski ${ }^{\mathrm{c}}$, F. Di Gangi ${ }^{\mathrm{d}}$, G. Borgogno ${ }^{\mathrm{e}}$, \\ M. Passarella ${ }^{\mathrm{e}, 1}$, C. Trovato ${ }^{\mathrm{e}, 2}, \mathrm{Y}$. Legendre ${ }^{\mathrm{c}, 3}$ \\ a Laboratoire GéoSciences Réunion, Université de la Réunion, Institut de Physique du Globe de Paris, Sorbonne Paris Cité, CNRS UMR \\ 7154,15 avenue René Cassin, CS 92003, 97744 Saint- Denis - cedex 9, La Réunion, France \\ b Observatoire Volcanologique du Piton de la Fournaise (OVPF), Institut de Physique du Globe de Paris, Sorbonne Paris Cité, CNRS, \\ UMR 7154 - Géologie des Systèmes Volcaniques, 14 RN3, le 27ème km, 97418, La Plaine des Cafres, La Réunion, France \\ C Institut de Physique du Globe de Paris, Sorbonne Paris Cité, CNRS, UMR 7154 - Géologie des Systèmes Volcaniques, 1 rue Jussieu, \\ 75005 Paris, France \\ d Instituto Nazionale di Geofisica e Vulcanologia, sezione di Palermo,Via Ugo La Malfa 153, 90146, Italy \\ e Observatoire Volcanologique et Sismologique de Guadeloupe, Institut de Physique du Globe de Paris, Sorbonne Paris Cité, CNRS, \\ UMR 7154, Le Houëlmont, 97113 Gourbeyre, Guadeloupe, France
}

\section{A B S T R A C T}

After a drastic decline in 1983, hydrothermal activity at La Soufrière lava dome (Guadeloupe, Lesser Antilles) has been progressively increasing in the summit area since 1992, raising the threat of a renewed eruptive activity. To better constrain the geometry of the hydrothermal system, an extensive high-resolution self-potential survey was performed on the dome and three multi-method profiles combining electrical resistivity tomography, self-potential, ground thermometry and soil $\mathrm{CO}_{2}$ diffuse degassing measurements were carried out to cover its south-ern periphery in January 2011. Results indicate that hydrothermal ascending flows are currently restricted to a proximal area including the dome and its very vicinity. The extension of hydrothermal alteration inferred from electrical resistivity tomography reflects the presence of a heat source just below the dome. A first-order correc-tion of topography-related self-potential variations allows the identification of major hydrothermal fluid circula-tions pathways, as well as significant meteoric infiltration zones. Local shifting of hydrothermal fluids towards the dome periphery is favored by the presence of major axes. The regional La Ty fault appears as the major axis draining large volumes of hydrothermal and magmatic fluids. However hydrothermal activity remains con-fined inside a collapse structure surrounding the dome, that formed in the last 9000 years as a result of recurrent edifice collapses, the latest occurring at the onset of the 1530 AD eruption. The combination of these qualitative results with structural analysis leads to a synthetic model of magmatic and hydrothermal fluids circulation inside the dome, which may be useful for the assessment of potential hazards associated with a renewal of fluid pres-surization, and a possibly associated partial flank-failure.

\section{Introduction}

The presence of well-developed hydrothermal systems on active volcanoes has been recognized as a major hazard factor for several reasons. Hydrothermal circulation usually alters and weakens the internal parts of volcanic edifices, increasing the risks of instability (López and Williams, 1993; Vallance and Scott, 1997; Reid et al., 2001;

\footnotetext{
* Corresponding author at: Laboratoire Magmas et Volcans, Université Blaise Pascal - CNRS - IRD, OPGC, 5 rue Kessler, 63038 Clemont-Ferrand, France. Tel.: + 33473 346723.

E-mail address: elodie_brothelande@yahoo.fr (E. Brothelande).

${ }^{1}$ Now at Wairakei Research Centre, GNS Science, 114 Karetoto Road, Taupo 3352, New Zealand.

2 Now at BRGM, 3 avenue Claude Guillemin, 45060 Orléans, France.

${ }^{3}$ Now at BRGM, Le Houëlmont, 97113 Gourbeyre, Guadeloupe, France.
}

Komorowski, 2008). Hydrothermal systems are unstable energy transfer systems, therefore, modifications of heat fluxes within the edifice can result in pressurization triggering phreatic explosions (e.g. Lube et al., in press) or favoring partial edifice collapse along low strength layers with higher fluid pore pressure and associated reduced friction (Reid et al., 2001; Komorowski, 2008). Additionally, hydrothermal systems can interact with magma, giving rise to highly explosive phreatomagmatic dynamisms. From these different perspectives, the hydrothermal system geometry and evolution appear as key parameters to better constrain volcanoes potential behavior and associated hazards. At La Soufrière volcano (Guadeloupe), flank collapse has been recognized as a repetitive phenomenon along the history of the volcano (Komorowski et al., 2002, 2005; Boudon et al., 2007; Komorowski, 2008; Legendre, 2012) and the major role of extended hydrothermal alteration in these events has been evidenced by recent works on the 
associated debris avalanche deposits (Salaün et al., 2011). The implication of the hydrothermal system has been proven in many eruptions, from phreatic crises to cataclysmic phreato-magmatic events (11 500 BP, 3100 BP; Boudon et al., 1992). Since the first descriptions in $1635 \mathrm{AD}$, this hydrothermal system has undergone many fluctuations, alternating between resting periods characterized by residual hydrothermal activity, fumarolic reactivations, and phreatic eruptions sometimes rather violent (Komorowski et al., 2005; David, 1998, and references therein). The last phreatic crisis, in 1976-77, resulted in the evacuation of 70,000 inhabitants of the island and a large scientific controversy on the presence of an eventual magmatic component, pointing out the lack of data available for hazard assessment and forecasting (Feuillard et al., 1983; Komorowski et al., 2005; Hincks et al., 2014).

La Soufrière is located just $5 \mathrm{~km}$ north to the town of Saint-Claude (10 000 inhabitants). Currently active, the volcano has been monitored through seismic, deformation (tiltmeters, GPS, extensometers, distancemeters) and geochemical (gas, fluid, spring, flux, and temperature analyses) networks since 1950 (Observatoire Volcanologique et Sismologique de Guadeloupe; OVSG managed by Institut de Physique Globe de Paris). After a drastic decline in 1983, hydrothermal activity has been slowly and progressively increasing in the summit area since 1992 , raising the threat of a new eruption. In the last decade, the Guadeloupe Volcanological and Seismological Observatory (OVSG-IPGP) has recorded a systematic progressive increase in shallow low-energy seismicity, a slow rise of temperatures of some acid-sulfate thermal springs (Villemant et al., 2005) close to the dome, and, most noticeably, a significant increase in the summit fumarolic activity associated with $\mathrm{HCl}$-rich and $\mathrm{H}_{2} \mathrm{~S}$ acid gas emanations (OVSG, 1999-2014; Komorowski et al., 2001, 2005). The permanent acid degassing from two summit highpressure fumaroles has caused vegetation damage on the downwind flanks of the dome and required the establishment by the authorities of a no-public access zone since 1999 that concerns the most active areas of the summit (Komorowski et al., 2005). At present time, a magmatic origin to this prolonged unrest cannot be excluded.

In the recent years, significant efforts have been made to characterize the geophysical structure of the dome (Nicollin et al., 2006; Coutant et al., 2012; Lesparre et al., 2012; Lesparre et al., accepted for publication). Yet, better constraints on the hydrothermal system geometry, and its relations with the main structural features of the edifice are still needed (Komorowski, 2008). Within this scope, we present here a combination of multi-electrodes high-resolution electric resistivity tomography (ERT), self-potential (SP), sub-surface temperature, and soil $\mathrm{CO}_{2}$ diffuse degassing to derive information on the location of the hydrothermal system over the volcano.

\section{Geological setting}

Basse-Terre Island (Guadeloupe archipelago) belongs to the northern part of the recent inner arc of the Lesser Antilles. La Grande Découverte-Soufrière (GDS) is an andesite-type explosive volcanic complex, representing the latest, and the only active, of six volcanic complexes composing the island. The construction of this volcanic complex started most likely 445 to 435 ka ago with the formation of La Grande Découverte. This edifice consists of thick lava flow sequences alternating with deposits from several major explosive eruptions (Boudon et al., 1988; Carlut et al., 2000; Komorowski et al., 2005; Samper et al., 2007, 2009) dated at about $140 \mathrm{ka}, 108 \mathrm{ka}$, and finally about $42 \mathrm{ka}$ ago during the Pintade eruption that produced the La Grande Decouverte caldera (Boudon et al., 1988; Komorowski et al., 2005). The second phase, from $42 \mathrm{ka}$ to $11.5 \mathrm{ka}$, corresponds to the construction of the Carmichaël edifice inside the La Grande Decouverte caldera. This phase ended with at least two major collapses (13.500 and 11.500 yrs BP) affecting the western flank of the edifice and forming the Carmichaël crater (Fig. 1). Following a non-magmatic partial collapse of the S-SE flanks of the remaining part of the Carmichael edifice at about 8200 yrs B.P. which formed the Amic crater, new effusive activity marked the onset of the third phase, called La Soufrière (Komorowski et al., 2005; Boudon et al., 2007; Legendre, 2012). Alternating effusive and explosive activity developed within the Amic structure which was widened by the occurrence of at least 8 distinct edifice collapse events, with the most recent event dated at 1530 AD (Komorowski et al., 2002, 2005; Boudon et al., 2007; Komorowski, 2008; Komorowski et al., 2008a; Legendre, 2012). One of the main effusive phases led to the formation of the Amic dome that preceded the formation of two scoria cones (L'Echelle and La Citerne) around 1700 BP. La Soufrière lava dome, culminating at $1467 \mathrm{~m}$ and representing the highest point of the Lesser Antilles, was formed during the last major magmatic eruption dated around $1530 \mathrm{AD}$ by radiocarbon dating (Boudon et al., 2008; Legendre, 2012; Komorowski et al., 2008b). The dome is surrounded by a collapse structure affecting the Amic dome and L'Echelle cone, formed or reactivated for the last time at the onset of the magmatic eruption (Boudon et al., 2008), and named after the event (Figs. 1, 2). Many fumaroles, temperature anomalies and thermal sources on the dome and its surroundings highlight the presence of a well-developed hydrothermal system, as a result of an enormous rainfall rate (7-10 m.y ${ }^{-1}$ on the summit area; OVSG-IPGP, 1999-2013; Villemant et al., 2005) combined with the existence of permanent heat sources at depth. The dome is cut by numerous fractures (Fig. 2; Nicollin et al., 2006; Lesparre et al., 2012) mainly radial to the summit. Most of the main fractures opened during historic phreatic eruptions (1690, 1797-98, 1809-12, 1836-37, 1956 and 1976-77; Boudon et al., 1988; Komorowski, 2008). The north-south fractures, Fente du Nord to the north and La Ty fault to the south-east of the dome, correspond to a system of regional active tectonic faults crossing the dome (Fig. 1; Feuillet, 2000; Feuillet et al., 2002; Mathieu et al., 2013). La Ty fault intersects the base of the dome and can be followed in the landscape up to Ravine la Ty and the south-western flank of La Citerne cone (Figs. 1, 2). Five major explosion craters are present at the summit of the dome: Tarissan, Dupuy, Napoleon, Cratère Sud, and Cratère 1956 (Fig. 2). During the latest eruptions, explosive phreatic activity mostly affected the south-eastern part of the dome, but some of the northern structures were also active albeit to a lesser extent (Fig. 2). During the last phreatic eruption in 1976-1977, explosive activity, which started on the eastern flank by reactivating the pre-existing 1956 fractures, led to the opening of two new large fractures on July 8th to the east and on August 30th to the south-east of the dome (Fig. 2). Activity then migrated to the summit area where it was concentrated at the central Tarissan crater. Throughout the eruption, water vapor and acid gases mixed with non-juvenile blocks and ash were emitted at a high flux from the Tarissan crater (Feuillard et al., 1983; Komorowski et al., 2005). The 1976-1977 eruption has been interpreted as a stillborn magmatic or failed magmatic eruption by Feuillard et al. (1983) with the data available at the time. On the basis of new data and analytical techniques, Villemant et al. (2005), Boichu et al. (2008, 2011), and Ruzié et al. (2012) have confirmed this hypothesis.

After the 1976-1977 eruption, a decline of fumarolic activity was observed both on the summit and at the base of the lava dome (notably by the disappearance in 1984 of the Col de l'Echelle fumaroles along the eastern end of July 8th fracture). Only minor degassing still remained along the La Ty fault (Zlotnicki et al., 1992). Since 1992, a slow and progressive increase of fumarolic degassing has been observed. The reactivation of the summit fumaroles began at Cratère Sud in 1992 (Zlotnicki et al., 1992), at Napoléon crater in 1996-1997 and then at Tarissan crater in 1997 (OVSG-IPGP, 1999-2014; Komorowski et al., 2001, 2005). More recently, fumarolic activity resumed at Cratère 1956 in 2007 and two new fumaroles appeared in the summit area in December 2011 and October 2013 (Figs. 1, 2). The renewal of fumarolic activity is associated with $\mathrm{HCl}$-rich and $\mathrm{H}_{2} \mathrm{~S}$ acid gas emanations (volcano observatory reports) and, at the SW base of the volcano, with a slow rise of temperatures at three acid-sulfate thermal springs (Villemant et al., 2005). In parallel, the volcano observatory has recorded since 1992 a progressive increase of shallow low-energy volcano-tectonic earthquakes (OVSG- 


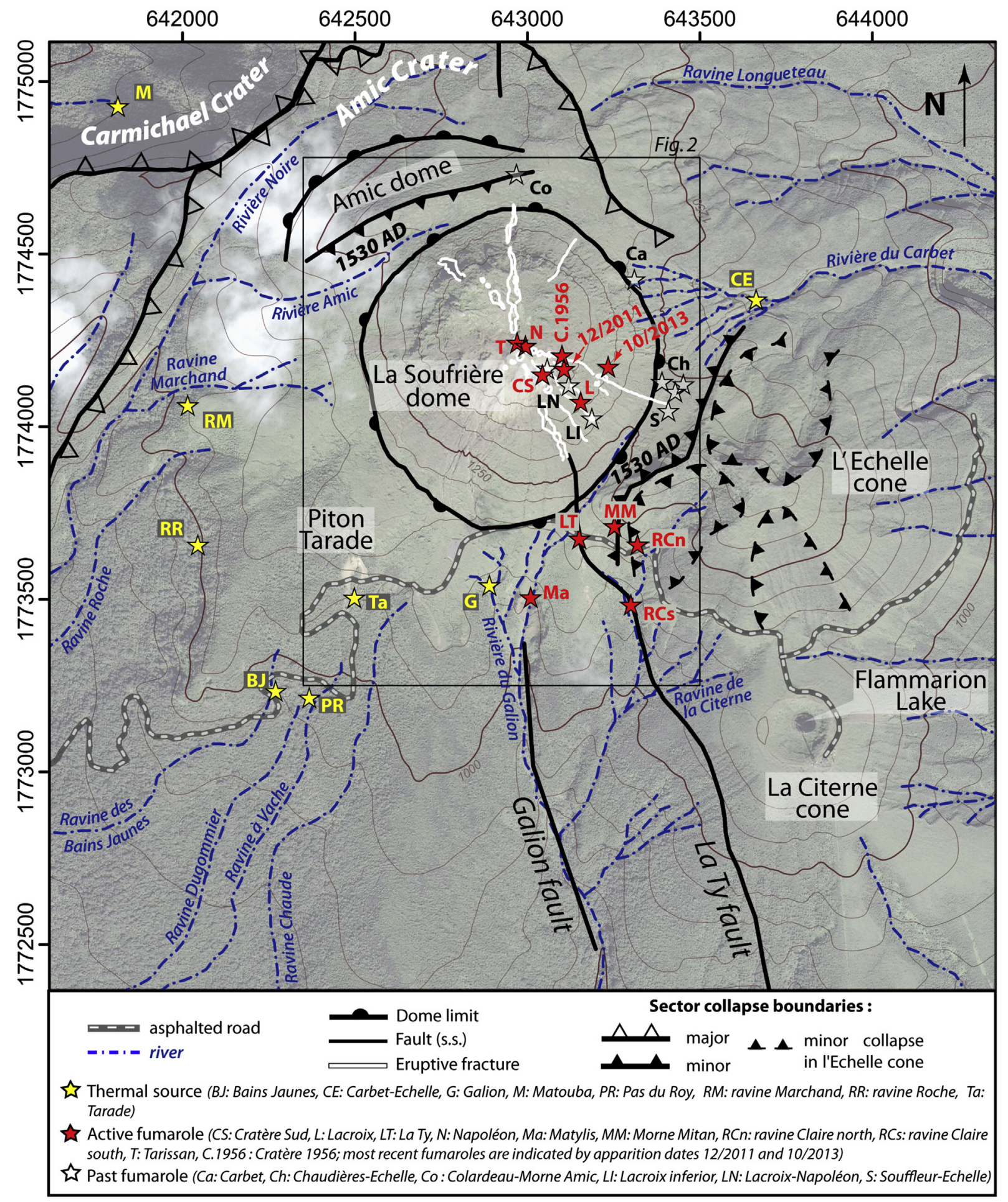

Fig. 1. Structural sketch map of the main structures in La Soufrière dome area. Location of the thermal sources, the active and past fumaroles are also shown. WGS84 geodetic system, UTM20N projection (m). After Feuillard et al. (1983), Boudon et al. (1988), Komorowski et al. (2005), Nicollin et al. (2006), Komorowski (2008).

IPGP, 1999-2014). The increase of the hydrothermal activity since 1992 and associated seismic unrest is not currently associated with any clear signs of magma ascent at shallow depth (deep seismicity with upward migrating hypocenters, or significant ground deformation). Nevertheless, there is clear evidence for the magmatic origin of chlorine-rich fluids feeding hot springs and the marked summit degassing that began in 1998 (Komorowski et al., 2001, 2005; Villemant et al., 2005; Li et al., 2012).

\section{Methods}

In order to better constrain the geometry of past and present hydrothermally active zones beneath the dome, we have simultaneously undertaken electrical resistivity tomography, self-potential, temperature and soil degassing surveys (Fig. 3). The entire acquisition was completed in less than a month (January-February 2011) under overall constant weather conditions. 


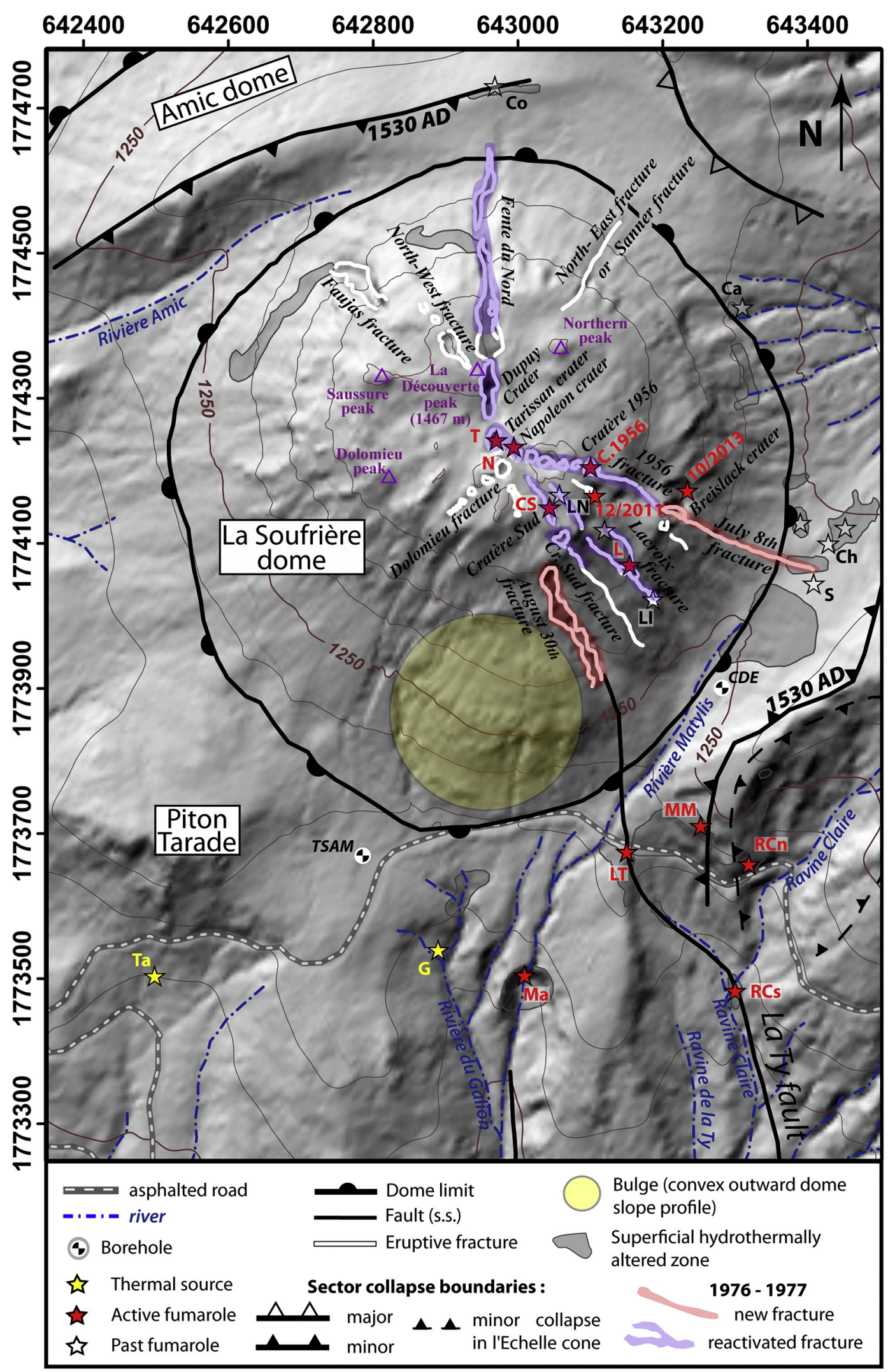

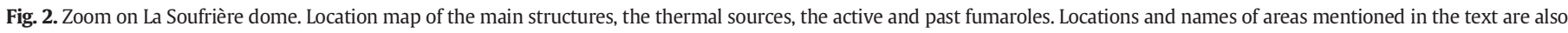
reported. WGS84 geodetic system, UTM20N projection (m). After Feuillard et al. (1983), Boudon et al. (1988), Komorowski et al. (2005), Nicollin et al. (2006), Komorowski (2008).

\subsection{Electrical Resistivity Tomography (ERT)}

The data acquisition was performed with a multi-electrode ABEM system (Terrameter SAS4000) driving cables equipped with 64 plugs to connect grounded stainless steel electrodes. The multi-electrode system possesses a relay matrix switcher, which chooses the two electrodes used to inject the electrical current in the ground and the two electrodes to measure the electrical potential. The acquisition followed 


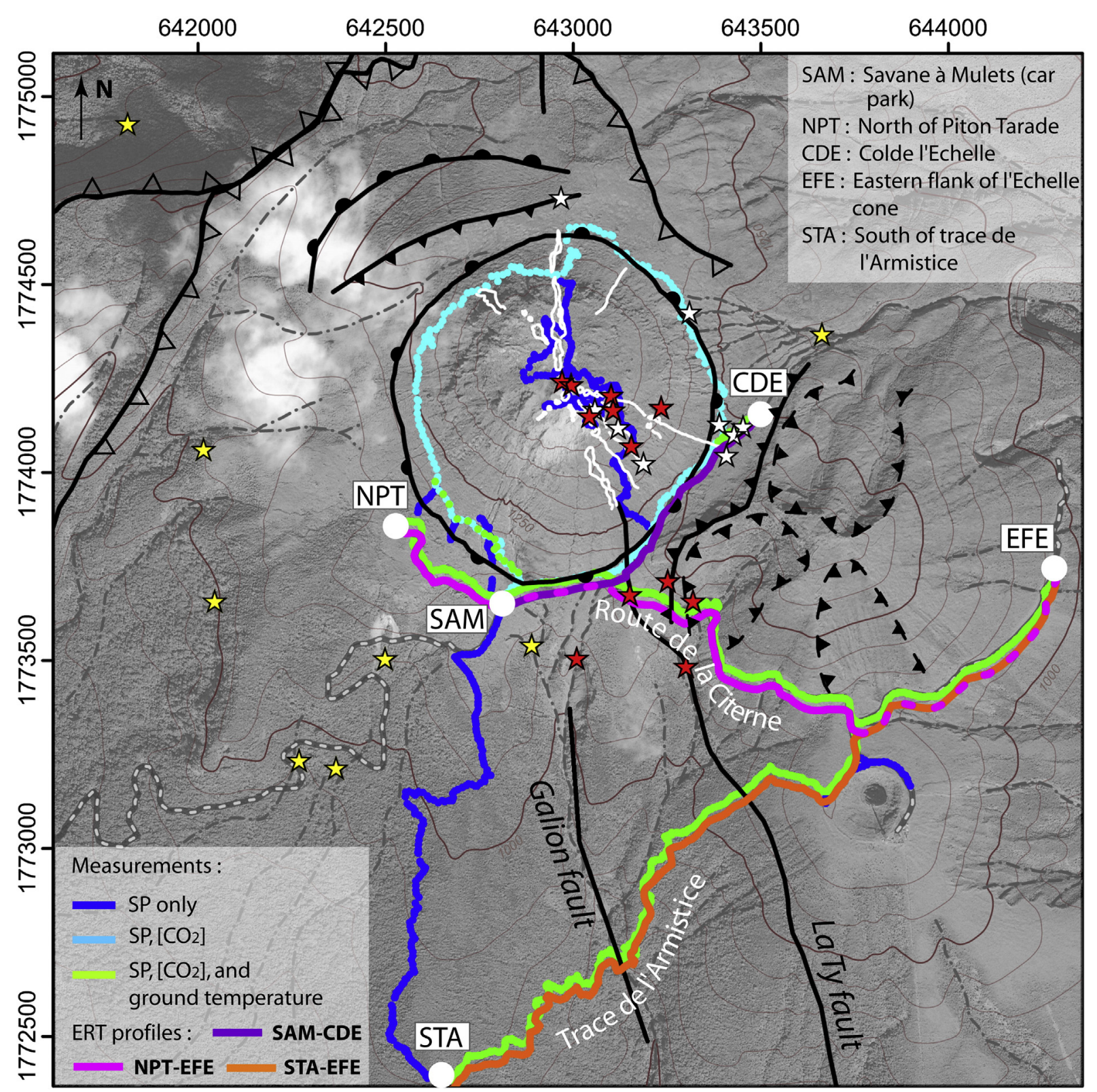

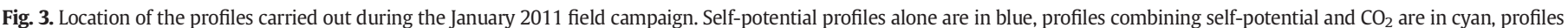

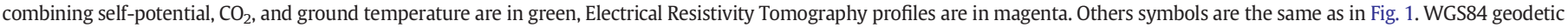
system, UTM20N projection (m). (For interpretation of the references to color in this figure legend, the reader is referred to the web version of this article.)

a Wenner protocol, providing a good signal-to-noise ratio, and a good sensitivity to vertical resistivity contrasts. Every measurement was repeated several times (stacking) and the standard deviation (error) was calculated. The set of cables used in the field operations have an electrode spacing of $15 \mathrm{~m}$, providing a total length of $945 \mathrm{~m}$ and a maximum depth of investigation of about $150 \mathrm{~m}$. The total length can be increased by roll-along processes.

After the acquisition, resistivity data was first filtered on the basis of quality criterions. Secondly, artifacts in the signal generated by surface heterogeneities were removed with the help of X2IPI commercial software (See Appendix A). Resistivity data was then inverted using RES2DINV commercial software (Loke and Barker, 1996), using a smoothness-constrained method to perform the inverse problem. This software, developed for environmental geophysics, has been widely used in different kinds of geological environments and notably volcanoes (e.g. Finizola et al., 2006; Revil et al., 2008; Byrdina et al., 2009;
Revil et al., 2011; Barde-Cabusson et al., 2013; Portal et al., 2013). Electrode positions were obtained by GPS measurements, and elevation was deduced from a one-meter resolution Digital Elevation Model of the dome. The topographic profile was included in the inversion to produce 2D-pseudosections.

Given that precise ERT had already been carried out on the dome itself (Nicollin et al., 2006), we concentrated our effort on the S-SW peripheral zone where fumarolic activity on La Ty regional fault is persistent since the end of the eighteen century. Three main profiles have been carried out: a $945-\mathrm{m}$ long profile between Savane à Mulets (SAM) and col de l'Echelle (CDE), a 2430-m long profile between the north of Piton Tarade (NPT) and the eastern flank of l'Echelle cone (EFE), and a 2925-m long profile between the eastern Flank of l'Echelle cone (EFE) and the south of trace de l'Armistice (STA; Fig. 3). ERT results should, as much as possible, be compared with other geophysical techniques to ensure that deep structures revealed on the profiles are not 
artifacts resulting from data processing-itself, and to distinguish ambiguities in the interpretation of the $2 \mathrm{D}$ resistivity cross sections.

\subsection{Self-potential (SP)}

During the campaign, more than $10 \mathrm{~km}$ of SP profiles were carried out, with an electrode spacing of $5 \mathrm{~m}$ (along the ERT profiles) to $10 \mathrm{~m}$ (around the dome; Fig. 3). Self-potential (SP) measurements were performed with a pair of non-polarizing $\mathrm{Cu} / \mathrm{CuSO}_{4}$ electrodes. The difference of electrical potential between the reference electrode (at one extremity of the profile) and the moving electrode was measured with a high-impedance voltmeter $(0.1 \mathrm{mV}$ sensitivity) and a $300 \mathrm{~m}$-long insulated copper cable. We measured the electrical resistance together with the self-potential in order to check the signal quality. The electrical resistance between the two electrodes should always be ten times smaller than the internal impedance of the voltmeter (Corwin and Hoover, 1979). In our case, the electrical resistances were systematically comprised between 1 and $200 \mathrm{k} \Omega$, so largely smaller than the internal impedance of our high-impedance voltmeter (10 $\mathrm{M} \Omega$ ).

In purely hydrogeological environment (i.e. areas not affected by hydrothermal convection), a clear inverse and linear relation has often been observed between SP and elevation variations (Corwin and Hoover, 1979; Jackson and Kauahikaua, 1987; Aubert et al., 1993; Finizola et al., 2004). The parameters of this relation are notably dependent on the type of rocks, kind of fractures, etc. The origin of this relation has been explained by various models (e.g. Zablocki, 1978; Fournier, 1983). In all cases, the variations of the SP signal reflect the variations of thickness of the unsaturated zone. In 1996, Aubert and Antagana have proposed an interpretation of SP variations in terms of SPS surface calculation (see Appendix B). Added to this general tendency, it has been observed that negative peaks locally highlight main infiltration zones (e.g. Finizola et al., 2002). On volcanic areas, numerous surveys have reported the presence of positive SP anomalies (a few hundred to a few thousand $\mathrm{mV}$ ) around areas affected by fumarolic activity and temperature anomalies (Zlotnicki and Nishida, 2003; Ishido, 2004; Revil et al., 2008; Finizola et al., 2009). Ascending hydrothermal fluids are believed to be the primary cause of these anomalies. This is due to the fact that most minerals in volcanic environments are characterized by a negative zeta potential (e.g. Aizawa et al., 2008; Aizawa, 2008). In rare cases, the precipitation of secondary minerals may cause the inversion of the zeta potential, and reverse the sign of anomalies related to ascending fluxes (e.g. Guichet et al., 2006; Jouniaux et al., 2009). $\mathrm{X}$-ray diffraction was performed on hydrothermal clays sampled in La Ty fault and near Cratère Sud, and revealed the presence of kaolinite, illite and smectite. As the $\mathrm{pH}$ of hydrothermal fluids sampled on the dome and peripheral hot springs (OVSG; Ruzié et al., 2013) is comprised between 2 and 6 , the zeta potential most probably remains negative and the sign of anomalies is not reversed (Chorom and Rengasamy, 1995; Hussain et al., 1996; Yukselen and Kaya, 2003; Saka and Güler, 2006; Yukselen-Aksoy and Kaya, 2010).

Typically, the SP signal on La Soufrière volcano reflects a combination of different contributions: topography, upward and downward local circulations. In previous surveys (1987, Pham et al., 1990; 1992, Zlotniki et al., 1994; 2000, Zlotnicki et al., 2006), these contributions are taken into account qualitatively for interpretation. By looking at the SP/elevation gradient, we tried to detect the contribution of elevation-dependent SP variations on the dome sector. We can therefore propose a "corrected SP", in which remaining anomalies would reflect either hydrothermal fluxes (positive anomalies) or preferential infiltration zones (negative anomalies; Fig. 4). Additionally, local variations of the SP signals were interpreted in terms of superficial water-saturated zones along multi-methods profiles (Figs. 5, 7; Appendix B).

\subsection{Temperature}

Temperature was measured with thermal probes placed at $30 \mathrm{~cm}$ depth with a spacing of $15 \mathrm{~m}$ (see Finizola et al., 2003). The temperature profiles provide an independent way to see the extension of the hydrothermal body near the ground surface, and therefore complete the information derived from SP.

\subsection{Soil $\mathrm{CO}_{2}$ degassing}

Soil $\mathrm{CO}_{2}$ diffuse degassing measurements were performed with a $15 \mathrm{~m}$ spacing. The detail of the methodology is described in Chiodini et al. (1998). Soil gas samples were taken at $30 \mathrm{~cm}$ depth by pumping with a syringe through a tube of copper ( $2 \mathrm{~mm}$ in diameter). $\mathrm{CO}_{2}$ concentrations were obtained as a difference of potential after calibration of an infrared photoelectric cell (IR spectrometer). Data distribution was then analyzed by a general statistical method detailed by Sinclair (1974), in order to detect the presence of Gaussian populations among the entire data set. The major part of the samples appears to belong to a single population characterized by a very low mean concentration (1400 ppm), corresponding to the contribution of biological processes added to atmospheric $\mathrm{CO}_{2}$. A minor but significant part of the samples is characterized by much higher concentrations (reaching 91\%). These samples are considered anomalic, reflecting the contribution of magma degassing.

\section{Results}

\subsection{SP map of the dome}

Fig. 4A shows the results of the SP survey on the dome. Given its variability along profiles in this sector, the elevation parameter probably has a significant influence on SP variations. Indeed, our set of data, as well as previous SP surveys (Pham et al., 1990; Zlotniki et al., 1994), shows a major positive anomaly at the base of the dome, and major negative anomaly on the very summit (Figs. 2, 4A), which is exactly what can be expected from a topographic effect. In addition, if the zeta potential is negative as observed on most volcanoes, the coexistence of a major negative anomaly and a major fumarolic zone on the summit area can hardly be explained. Thus, topography contribution to the signal needs to be distinguished from other effects by analyzing the SP-toelevation gradient behavior. Although La Soufrière has a probably complex structure in terms of permeability, resistivity distribution and hydrological geometry (Zlotniki et al., 1994), a first-order negative correlation between SP and elevation can be estimated from the whole data set, and an average value of $-0.55 \mathrm{mV} / \mathrm{m}$ can be subtracted to the original SP data (Fig. 4). The idea of a general behavior of the SP signal regarding elevation is supported by recent studies suggesting a common geochemical background for all thermal springs around the dome (Ruzié et al., 2013; Allard et al., 2014; Chen et al., 2014). The general topographic effect may be attributed to a deep, and more or less tabular aquifer. Elevation corrected SP map (Fig. 4B) offers at least a partial correction of a significant parameter that undoubtedly hides short wavelength anomalies related to water circulation, and provides a better correlation with observations on the summit area. A positive anomaly on the south-eastern part of the summit (DSum +) matches the fumarolic area between Tarissan crater, Cratère 1956 and Cratère Sud. Another positive anomaly on the lower part of the south-western flank (DSW +) may indicate hydrothermal circulation in this part of the dome, that has not yet been affected by phreatic or fumarolic activity at the surface. Negative anomalies on the northern flank and on the southern border of the dome indicate that these areas are dominated by descending fluxes of meteoric fluids. Pink stars within these areas or outside (DSum-, DNE -, DLac-, DCS -, DA30-, DSE -, DS1-, DS2 -, DS3 -, DS4 -, PT -; Fig. 4B) locate negative peaks observed on SP profiles, reflecting preferential infiltration pathways. Indeed, these 

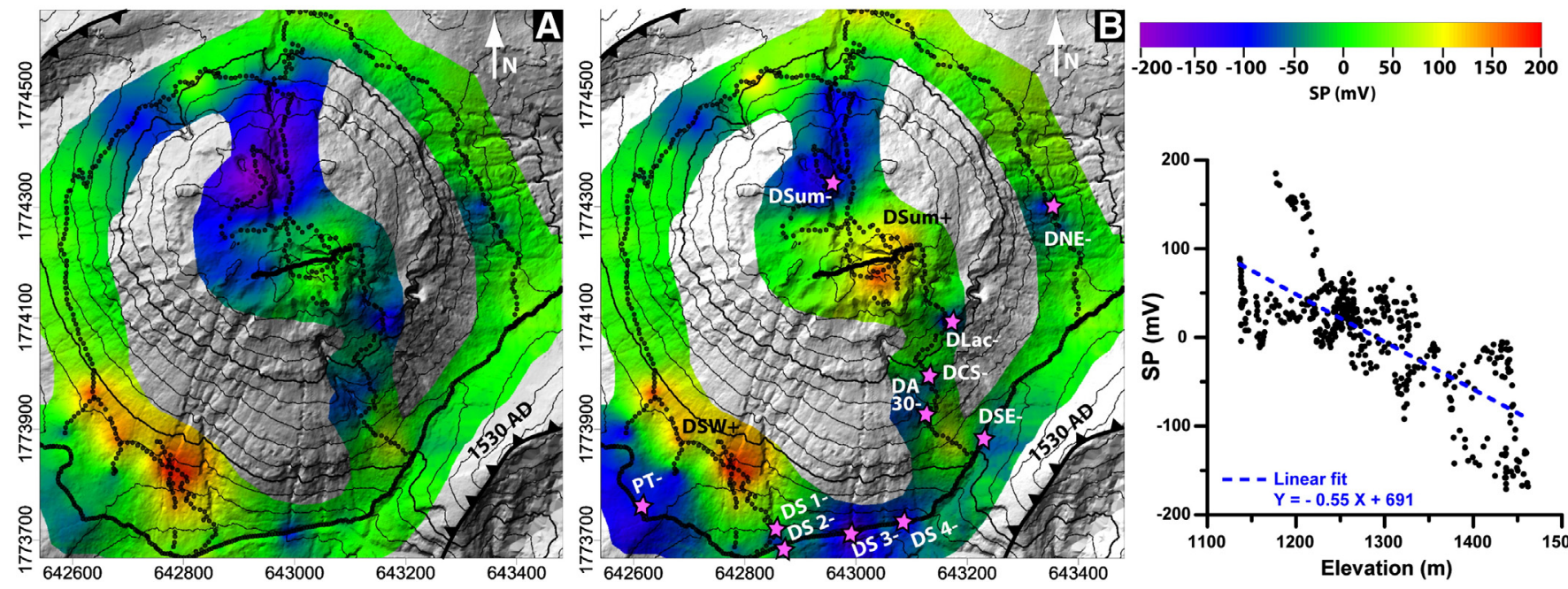

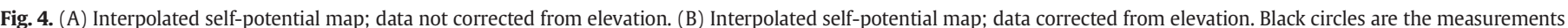

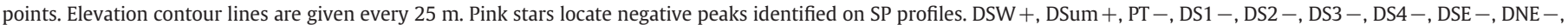

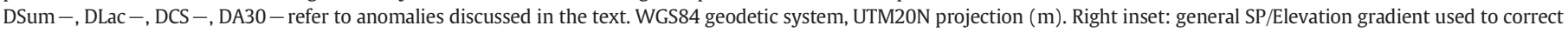
SP data. (For interpretation of the references to color in this figure legend, the reader is referred to the web version of this article.)

peaks are generally correlated to the presence of fractures: DSum - coincides with Fente du Nord, DLac - with Lacroix fracture, DCS - and DSE - with Cratère Sud fracture, and DA30 - with August 30th fracture. Other peaks are mostly located at the intersection with gullies.

\subsection{Detailed multi-method profiles}

\subsubsection{Dome and proximal vicinity}

Profile "SAM-CDE" joining Savane-à-Mulets to Col de l'Echelle intersects the major axes affected by the latest phreatic eruption (Fig. 5). On this profile, the root mean squared error (RMS) of the ERT section is $14.9 \%$ and calculated resistivity values range from a few tens to a few thousand ohm.m. SP values range from -110 to $+90 \mathrm{mV}$ and $\mathrm{CO}_{2}$ concentration values in soil gas are below $25,000 \mathrm{ppm}$. The south-western part of the ERT profile reveals high resistivity values (>1000 $\Omega . m$ ). The main feature of this profile is the presence of a vertical limit (at about $270 \mathrm{~m}$ from the beginning of the profile and extending to a depth of $\sim 70 \mathrm{~m}$ ), with a sharp resistivity gradient, in coincidence with a negative SP anomaly (DS4-). This limit, located on the dome border, separates a resistant medium $(>500 \Omega$.m) to the south-west from a conductive one $(<50 \Omega . \mathrm{m})$ to the north-east. The dome is globally made of very low resistivity material, thought extreme values $(<15 \Omega . \mathrm{m})$ bordering the resistivity contrast are poorly constrained according to the sensitivity study of this profile ("depth of investigation" DOI, in Appendix A). A more resistant layer (a few hundred ohm.m), about 20 m-thick, lies above this conductive body.

The SPS surface (Fig. 5B) calculated from SP variations (Appendix B), that may represent the upper limit of the water-saturated zone, supports the idea that the conductive body is saturated in fluids. Smallscale anomalies such as DS2-, DS 3 - and DS 4 - represent the maximum infiltration zones in the global negative anomaly at the south of the dome (Fig. 4). The two negative peaks DS2 - and DS3 $-(\triangle \mathrm{SP}<$ $-70 \mathrm{mV}$ ) are in perfect correspondence with the location of two north-south gullies at the surface (Fig. 5A).

The western part of the ERT profile "SAM-CDE" is common with the ERT profile joining the north of Piton Tarade (NPT) to the eastern flank of L'Echelle cone (EFE) (RMS 16.5\%; Fig. 6). Nonetheless, this common portion being further from the extremity in the ERT profile "NPT-EFE", we have access to a greater depth. The same resistive pattern can be observed on the two profiles indicating coherence between different acquisition results and limited edge effects on the ERT profile "SAM-
CDE”. The superficial zone of high resistivity, including Piton Tarade and with a typical thickness of $70 \mathrm{~m}$, is lying on top of a very conductive layer (resistivity $<50 \Omega \mathrm{m}$ ). This system of horizontal layers is interrupted to the east by a $100 \mathrm{~m}$-wide vertical conductive axis corresponding to La Ty fumarolic area, with comparably low resistivity values. Even if the Wenner array is less sensible to horizontal resistivity contrasts than to vertical, the presence of a conductive axis is supported by a major thermal and $\mathrm{CO}_{2}$ anomaly (Fig. 6) with a thermal flux of $275 \mathrm{~W} / \mathrm{m}^{2}$ (Gaudin et al., 2013). Upwelling of hydrothermal fluids is apparently not associated with any significant SP anomaly in this area. This may be explained by the very high conductivity of the material within the fault, or by the fact that the zeta potential may be close to zero (in response to secondary mineralization and very acidic fluids) in this particular zone. A sharp vertical resistivity contrast, up to the maximum depth of the tomography profile $(\sim 170 \mathrm{~m})$, separates this western domain from a globally resistive eastern domain. This boundary is located in the vicinity of collapse limits ( $1530 \mathrm{AD}$ collapse and minor sector collapse of l'Echelle cone). In the eastern part of the profile (beyond the collapses scars), resistivity values vary from a few hundred to a few thousand ohm.m. Being located rather far away from the dome, this portion is considered to belong to a distal domain (see Section 4.2.2).

\subsubsection{Southern peripheral zone}

The eastern part of ERT profile "NPT-EFE" is a globally resistant domain in comparison to dome-proximal sections (Fig. 6). In this portion of the profile "NPT-EFE", no temperature or $\mathrm{CO}_{2}$ anomaly can be found. Resistivity values range from a few hundred to a few thousand ohm.m, with almost no values inferior to $100 \Omega$.m.. The DOI study (Appendix A) indicates that resistivity variations in the central part of the profile are poorly constrained. To the very east of the profile, conductive bodies (a few hundred ohm.m) CN2 and CN3 reach the surface.

The ERT profile "STA-EFE" (RMS 10.02\%) joins the south of Armistice path to the eastern flank of l'Echelle cone (Fig. 7). Results on the eastern portion, common with ERT profile "NPT-EFE", confirm the presence of a system of vertical moderately conductive bodies including CN2, CN3 (already detected on the profile "NPT-EFE") and a third one, CN1, on the eastern part of L'Echelle-La Citerne complex. These axes seem to be related at depth to a conductive body extending westward with depth. The superficial structure of La Citerne western flank is dominated by resistant material cut by three relatively sharp vertical moderately conductive axes named CW1, CW2, and Ga that reaches the surface in coincidence with the Galion River bed (Fig. 7). Temperature and $\mathrm{CO}_{2}$ 

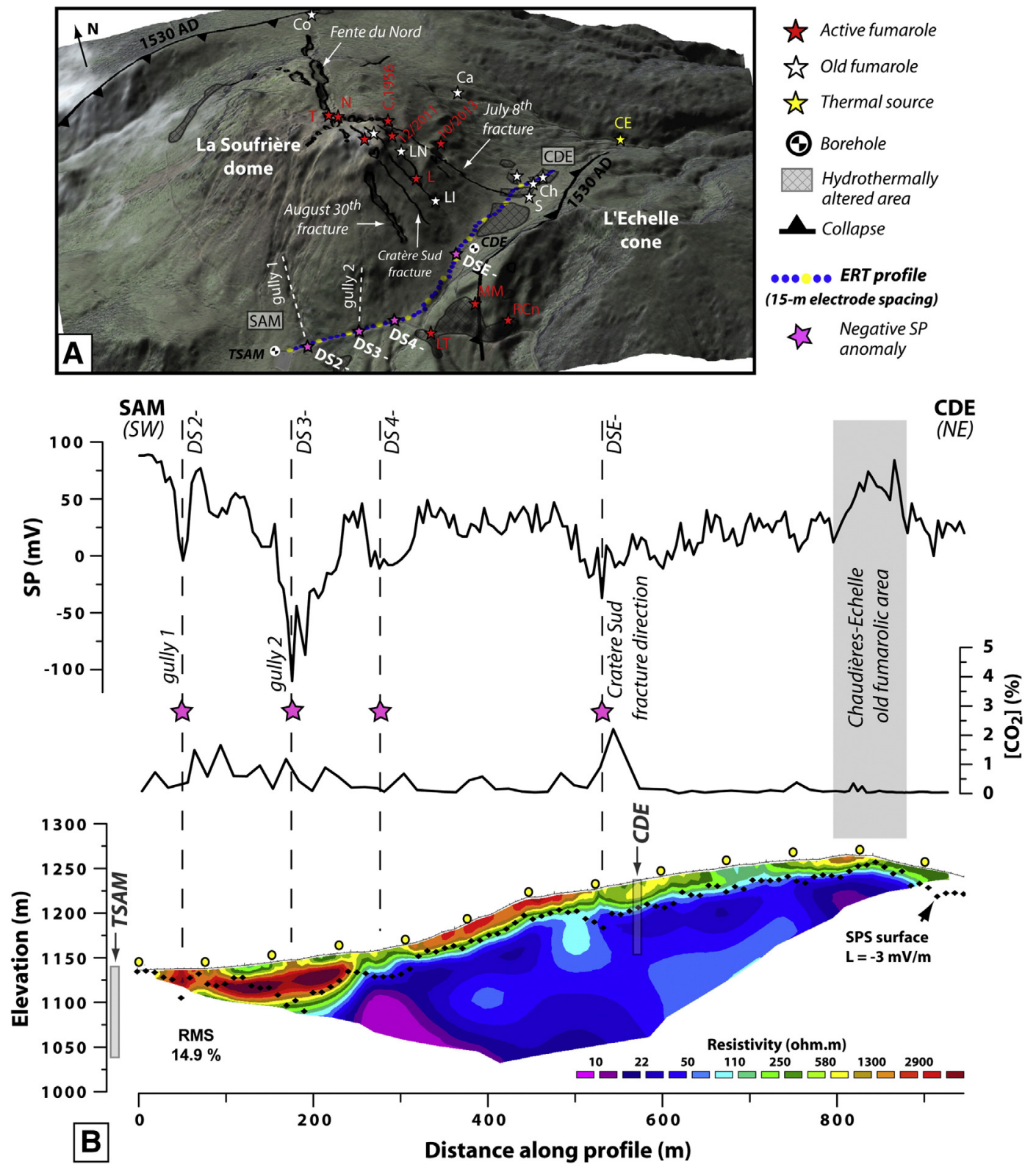

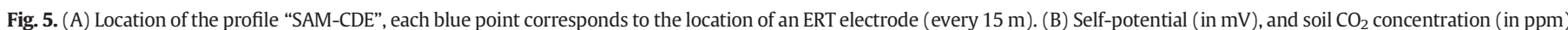

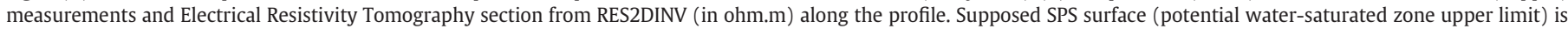

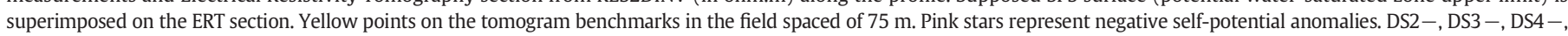

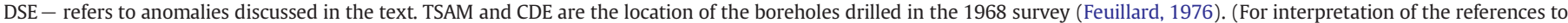
color in this figure legend, the reader is referred to the web version of this article.)

exhibit no anomaly. SP signal exhibits large wavelength variations with a minimum and a maximum peak respectively coinciding with the maximum elevation and the Galion River bed (minimum elevation). Interpretation of these variations in terms of SPS surface variations globally matches the fluctuation of the resistivity contrast at depth, indicating that conductive bodies may be saturated in hydrologic fluids.

\section{Interpretations and discussion}

The combined analyses of electrical resistivity tomography, selfpotential, ground thermometry and soil $\mathrm{CO}_{2}$ diffuse degassing measurements allow us (1) to image the hydrothermal circulations inside La Soufrière dome, $(2)$ to characterize the main structural axes in the southern periphery of the dome, and (3) to better define the hydrogeologic system of the L'Echelle-La Citerne complex.

\subsection{Model of hydrothermal circulations inside La Soufrière dome}

Results of the ERT survey tend to show that hydrothermal flows are confined to the dome and its very vicinity. Indeed, the profiles (Figs. 5, 6, 7) display a wide range of resistivity values that reflects variations of water content and alteration level of the andesitic material constituting the volcano. Very low values in the order of magnitude of tens of ohm.m are limited to the dome sector (proximal area), and can be interpreted as hydrothermally altered material (Figs. 5, 6). On the other hand, further from the dome (distal area), variations from a few hundred to a few thousand ohm.m are typical of resistivity variations in hydrologic systems (Figs. 6, 7).

The state of hydrothermal alteration within the dome, supported by various studies (Nicollin et al., 2006; Lesparre et al., 2012; Lesparre et al., 2014), is in agreement with gravity and magnetic data, suggesting that 

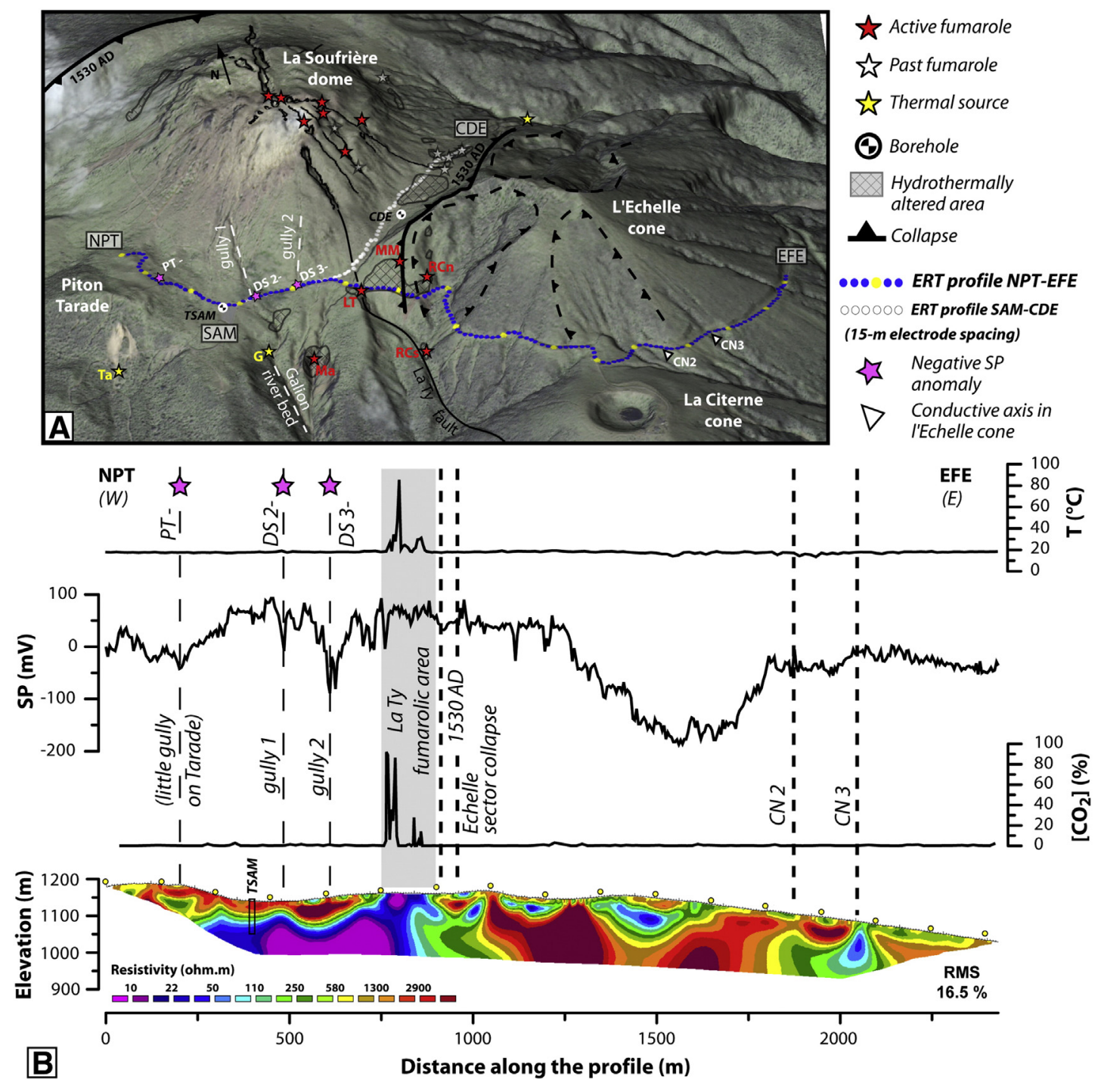

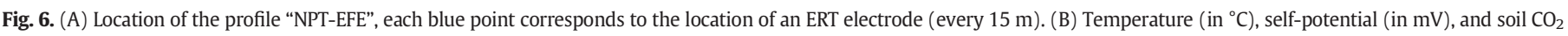

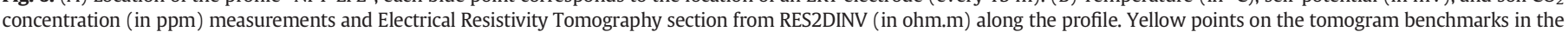

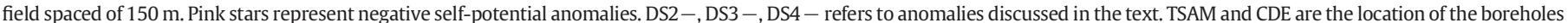
drilled in the 1968 survey (Feuillard, 1976). (For interpretation of the references to color in this figure legend, the reader is referred to the web version of this article.)

the dome is made of low density (about $1800 \mathrm{~kg} \cdot \mathrm{m}^{-3}$ ) extensively altered material (Gailler et al., 2013) as well as numerous conduits, wide fractures, and craters. Large conductive bodies at depth (around a few tens of ohm.m) to the north and to the south-east can be related to the presence of phreatic fractures and craters at the surface (Fig. 2). These conductive reservoirs and related fractures are currently associated to local negative SP anomalies at the surface visible on Fig. 4 (e.g. DSum - on Fente du Nord, DLac - on fracture Lacroix). Fig. 5 suggests these water saturated bodies may lie just below the surface. Whereas they probably play a major role in explosive phreatic crises, they may be sealed during inter-eruptive periods. These reservoirs constitute a major threat in the case of a continuing reactivation of the hydrothermal activity.

Most of the hydrothermal ascending fluxes, highlighted by the presence of fumaroles, SP positive anomalies (Fig. 4B), and high values of ground temperature and $\mathrm{CO}_{2}$ soil diffuse degassing, are also concentrated on La Soufrière dome itself. This strongly suggests the presence of a heat source located just below the dome. Hydrothermal fluxes on the summit area are centered on Cratère Sud and Tarissan crater, in accordance with the presence of major fumaroles there since respectively 1992 and 1997 (Figs. 2, 4B). These fluxes have recently started to expand ca. $200 \mathrm{~m}$ away from the dome center along the east-oriented 1956-July 8th fracture (see 12/2011 and 10/2013 fumaroles on Figs. 1 and 2; OVSG-IPGP, 1999-2014). These fluxes are certainly driven inside the dome by a central conduit: evidence of low resistivity and low density material around this zone (Nicollin et al., 2006; Lesparre et al., 2012 ) is the signature of hydrothermal alteration. Probable ascending flows beneath the south-western base of the dome correspond to a recognized low density zone at depth (Gunawan, 2005; Coutant et al., 2012). Even if most areas affected by past and current fumarolic activity are located on the dome itself, some fumaroles can nevertheless be found in its proximal vicinity along major radial lineaments. This is the case for the formerly active Colardeau fumaroles in the direction of Fente du Nord (Co; Figs. 1, 2), the Chaudières and Souffleur fumaroles on the July 8th fracture (Ch, S), and the currently active fumaroles (LT) on La Ty fault, which was recognized as a regional structure (Feuillet et al., 2002). This suggests a strong control of the main radial structures on the hydrothermal flux distribution outside of the dome. The La Ty fumarole is characterized by large temperature and $\mathrm{CO}_{2}$ anomalies (Fig. 6), showing that this deep major accident conducts a significant part of hydrothermal and magmatic fluids towards the periphery of the dome. As illustrated by Petrillo et al. (2013) and Byrdina et al. 


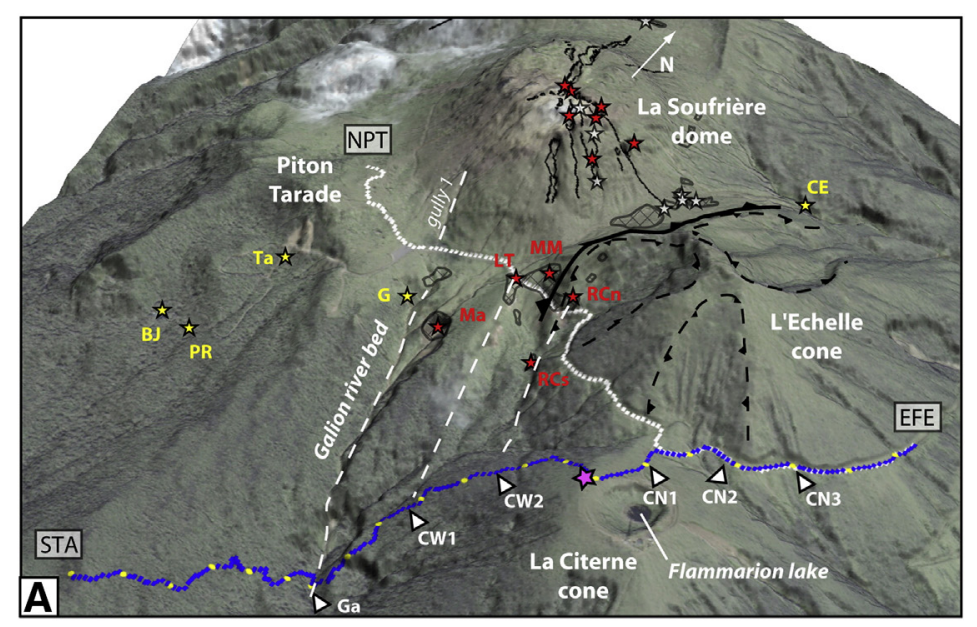

\author{
扥 Active fumarole \\ 政 Past fumarole \\ is Thermal source \\ Hydrothermally \\ altered area \\ ¿ Collapse \\ ๑ $\bullet$ ERT profile EFE-STA \\ 000000 ERT profile NPT-EFE \\ (15-m electrode spacing)
}
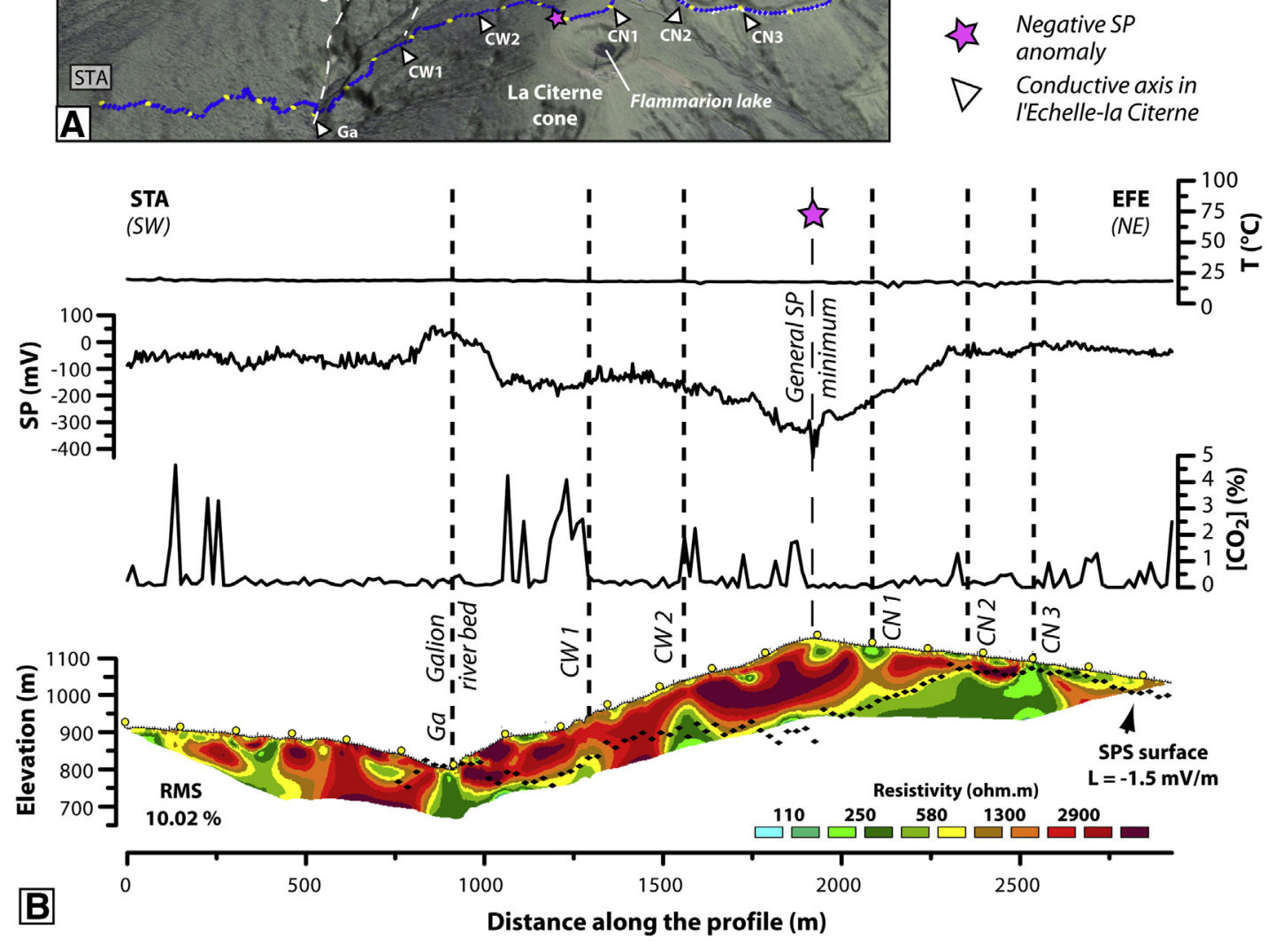

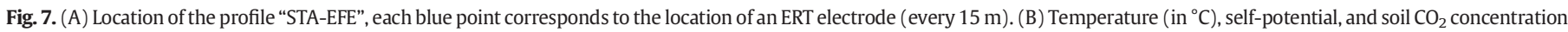

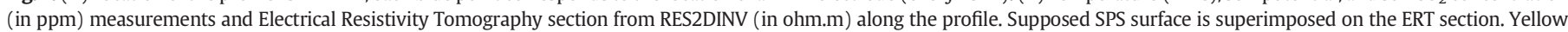

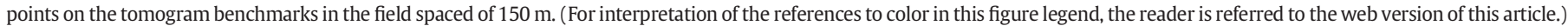

(2013), the shift of the hydrothermal system towards the periphery may result from a complex interaction between the depth of the heat source, the topography of the edifice and the permeability distribution. Fig. 8 gives a synthetic view of fluids circulation inside the dome. Hydrothermal ascending fluids are concentrated inside the dome and propagate laterally away from the dome along major accidents.

The lateral extension of hydrothermal ascending fluids outside the dome seems delimited by a peripheral limit. A major deep vertical resistivity contrast (at least $170 \mathrm{~m}$-deep) has been recognized on the profile "NPT-EFE" between La Soufrière and L'Echelle and corresponds to the limit of the most recent edifice collapse structure that surrounds the dome, and that was last reactivated at the onset of the 1530 AD eruption (Boudon et al., 2008). This structure, which cuts through the western part of the l'Echelle cone (Fig. 6), is probably the result of several collapse episodes occurred during the last 9150 years (Komorowski et al., 2008a; Legendre, 2012). The role of the collapse structures as fluid guides towards the surface is corroborated by the location of minor but persistent fumaroles such as Morne Mitan and Ravine Claire (MM, RCn, RCs; Figs. 1, 2). Additionally, the past Colardeau fumaroles, located at the intersection of the major Fente du Nord fracture and the northern edifice collapse limit on the Amic dome (Figs. 1,2), also suggests a control by the $1530 \mathrm{AD}$ collapse structure on the lateral extension of ascending hydrothermal fluids to the north.

The north-eastern part of the ERT profile "SAM-CDE" shows the conductive material constituting the dome is covered by a relatively thin resistant layer ( 20 m-thick; Fig. 5). Observations from a 79 m-deep borehole drilled in 1968 close to Col de l'Echelle (CDE, see Figs. 5 and 6 for location of the CDE and TSAM boreholes) revealed the presence of highly hydrothermalized andesitic material between 79 and $31 \mathrm{~m}$ depth, in agreement with the low resistivity values of the ERT section. On top of this material, lapilli and moderately altered ashes constitute a more resistant superficial layer. Part of this superficial material probably results from a lahar formed by mixing of water that was emitted by the resurgence of a perched aquifer through the July 8th fracture, with cold block-and-ash flow material explosively vented contemporaneously from the same fracture on July 8th in 1976 (Feuillard, 1976; Feuillard et al., 1983; Boudon et al., 1988; Komorowski et al., 2005; Feuillard, 2011). The ERT profile "NPT-EFE" shows the shallow levels 


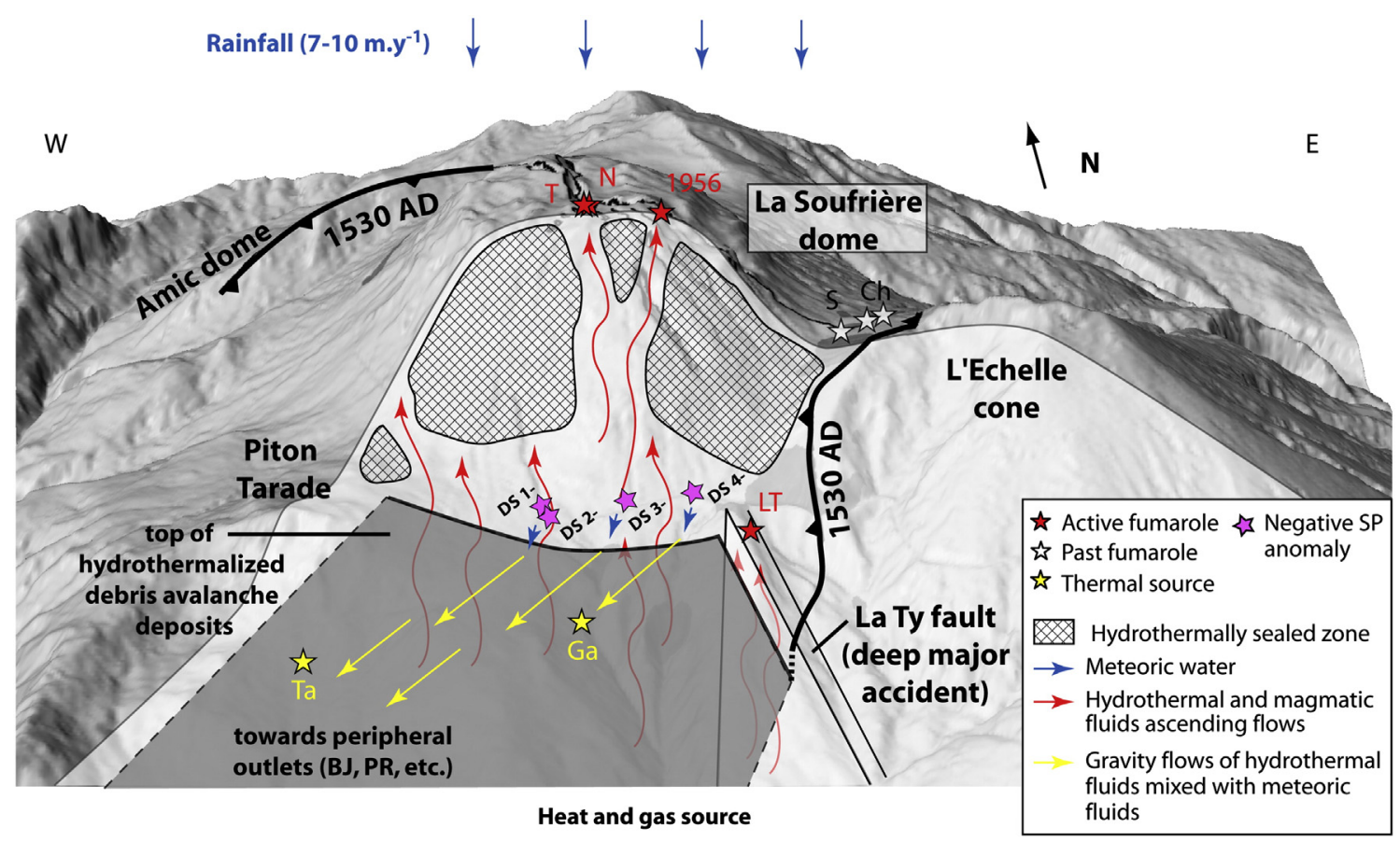

Fig. 8. Synthetic and simplified sketch map of fluids circulation inside La Soufrière dome.

of the southern rim of the dome are made of relatively unaltered material, represented by a $\sim 70$ m-thick resistant layer under the surface (Fig. 6). This resistant material, including Piton Tarade and extending up to La Ty fault to the east, lies over a very conductive layer of hydrothermalized material (resistivity $<50 \Omega$.m). This resistivity distribution well matches the overall succession of lithologies described in the 97 m deep TSAM borehole carried out in 1968 (Feuillard, 1976) in which massive - yet fractured and variably altered - andesite was found from the surface to $80 \mathrm{~m}$ deep, resting on top of strongly altered andesites. The horizontal limit between the two domains on the ERT section suggests a depositional contact between the two layers (Fig. 6). The deep conductive material seems to correspond to a conductive layer imaged by ERT under a large part of the dome (Nicollin et al., 2006). The horseshoe-shaped top of this basal layer suggests it resulted from one or several of the numerous flank collapses of hydrothermally altered material that preceded the dome formation (Komorowski et al., 2002, 2005; Boudon et al., 2007; Legendre, 2012). The geometry of this basal and probably impermeable layer, inclined towards the south, with a top reaching approximately $1100 \mathrm{~m}$ above sea level on the ERT section "NPT-EFE" (Fig. 6), makes it a good candidate to guide descending fluids towards peripheral sources located along roughly the same $900-1000 \mathrm{~m}$ isocontour, as suggested by geochemical tracing of meteoric water (Bigot et al., 1994; Komorowski, 2008; Lesparre et al., 2012). This layer was interpreted by Komorowski (2008) and Lesparre et al. (2012) as a low strength layer corresponding to the listric surface over which the edifice has recurrently collapsed. It is likely constituted by a sequence of sheared hydrothermally altered clay-rich debrisavalanche deposits from the successive events.

The contact between the resistant superficial layer and the dome itself (ERT profile "SAM-CDE"; Fig. 5) appears as a permeability barrier combining a strong resistivity contrast and a negative SP anomaly (DS4-). Its shallow vertical extension $(\sim 70 \mathrm{~m})$ and curved shape suggest it might represent the northern edge of an edifice collapse. A lava flow sample found within the top resistant material (58 m deep; Samper et al., 2009) and dated at 94 ka supports the hypothesis of an old lava flow remobilized during an edifice collapse event. This material is in continuity with Piton Tarade (Fig. 6) which is probably identified as a perched Toreva block (Komorowski, 2008). Indeed, field inspection of a moderate rockslide from Piton Tarade reported the deposits originated from an unusually shattered lava with local clastic fabric of subangular to subrounded blocks coated with hydrothermally altered material (Komorowski, 2008). This fabric, similar to the ones observed in the TSAM borehole and described by Feuillard (1976), is characteristic of allochtonous blocks that would have detached from a former edifice and slid on a short distance.

In terms of current fluid circulation, the superficial resistant layer to the south of the dome is cut by north-south oriented gullies coinciding with SP negative anomalies (DS1 -, DS2 - and DS3 - on gullies 1 and 2, Figs. 5, 6) that indicate preferential meteoric infiltration. These gullies are located on the bulging area of the dome (Figs. 2, 5). They are found above highest resistivity values, suggesting their location may be guided by superficial cavings. Given the north-south direction of these gullies, they might be the expression of minor faults, parallel to regional structures such as La Ty fault. Meteoric fluids infiltrated inside the dome most probably mix with a significant part of hydrothermal fluids that does not reach the surface, and may be guided above the conductive deep layer towards the south-west to feed eccentric thermal springs (Fig. 8). These springs are mostly located on the $900-1000 \mathrm{~m}$ isocontour interval that would form the intersection of the plane of the deep low strength conductive layer with topography.

\subsection{Characterization of the main structural axes in the southern periphery of the dome}

La Ty fault is described in literature as a major north-south, practically linear, normal fault intersecting the dome (Feuillet et al., 2002) through the August 30th fracture and Fente du Nord (Figs. 1, 2). Previous field observations suggested a nearly vertical fault, possibly eastward dipping according to the apparent subsidence of the eastern part of La Soufrière lava dome relatively to the western part (Feuillet, 2000; Feuillet, personal communication, from morpho-tectonic observations). This fault is undoubtedly recognized by a major fumarolic area in the very vicinity of the dome where anomalies of temperature and soil $\mathrm{CO}_{2}$ concentration characterize a major deep accident. This fumarolic zone is located at the intersection between "Route de la Citerne" pathway and a hydrothermalized crest emphasized in the landscape by 


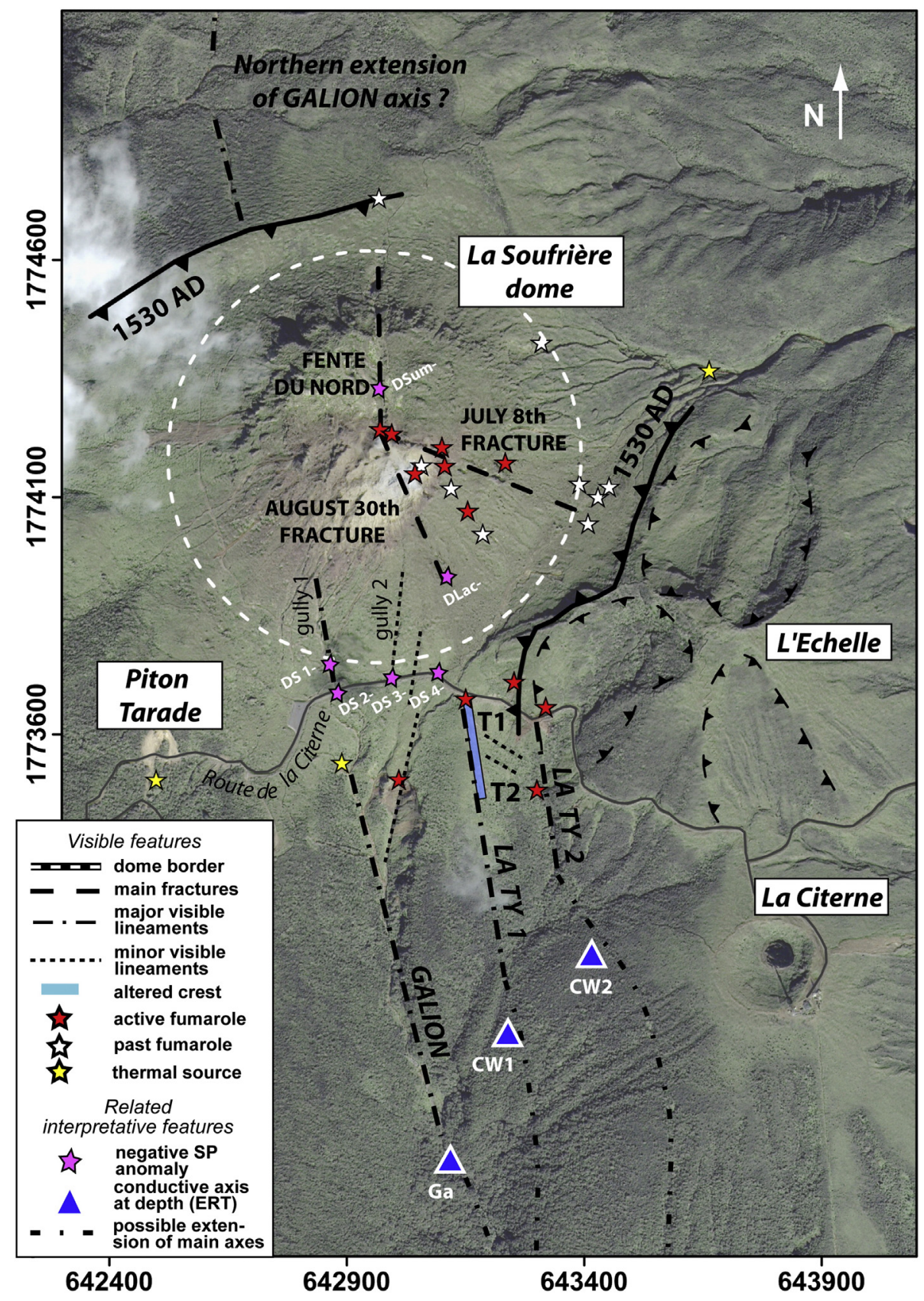

Fig. 9. Synthesis of the three main axes and associated ERT, SP, and thermal anomalies observed to the south of La Soufrière dome. WGS84 geodetic system, UTM20N projection (m).

the presence of outcropping altered material. This north-south linear crest (Axis "La Ty 1" in Fig. 9) is thought to represent the La Ty fault trace at the surface and is consistent with eastward dipping. This trace is a few hundred meters long and vanishes southward. Structural observations suggest the existence of two other parallel north-south axes. The first one (Axis "La Ty 2" in Fig. 9) is defined in its northern part by Ravine Claire, a valley parallel to Axis "La Ty 1" (Figs. 2, 9). The curved shape of its southward extension across La Citerne western flank evokes a westward dipping accident. Two transverse lineaments T1 and T2 suggest the existence of deformation between "La Ty 1" and "La Ty 2", which would be consistent with a conjugate normal fault system. A third axis "Galion" is defined by the relatively straight Galion river bed, also emphasized by the Galion thermal spring (Figs. 1, 9). This axis, recognized as a fault by Boudon et al. (1988), probably extends across the dome through the non-radial gully 1 . Two more lineaments might represent the extension of the "Galion" axis to the north of the dome (Fig. 9).
The idea of three distinct and parallel axes is consistent with ERT profile "STA-EFE" showing three conductive axes crossing La Citerne western flank (Fig. 7): Ga is clearly connected to the Galion river bed, and CW1 and CW2 might be respectively related to structural axes La Ty 1 and La Ty 2 (Fig. 9). CW1, CW2 and Ga do not show any anomaly related to hydrothermal circulation; and apparent positive SP peak coinciding with Ga (Fig. 7) is thought to be a local topographic effect. Low resistivity values suggest that, far from the dome, these structural axes constitute preferential infiltration zones for meteoric waters (Fig. 9).

Although regional tectonics suggest a unique segment for the La Ty regional normal fault, further observations indicate that the extensional system may be more complex on a local scale and that normal movement may have been accommodated by a relay of parallel and conjugated faults. This local tectonic complexity probably favored the formation of several fractures on the south-eastern portion of the dome during recent historical explosive eruptions characterized by significant 
hydrothermal fluid overpressure, in 1956 and especially in 1976. These dynamic processes coupled with extended acid alteration from prolonged hydrothermal activity have certainly affected the dome mechanical properties.

\subsection{Hydrologic system of the L'Echelle-La Citerne edifices}

The ERT profile "STA-EFE", as well as the eastern part of the ERT profile "NPT-EFE", can be considered as distal from La Soufrière dome (Fig. 3). The lack of very low resistivity values can be linked to the absence of hydrothermal alteration in this sector (Figs. 6, 7). Variations of resistivity, ranging from a few hundred to a few thousand ohm.m, can be interpreted in terms of lithology and hydrologic systems. As L'Echelle and La Citerne are considered as relatively homogeneous scoria cones with a few minor localized lava flows (Boudon et al., 1988), coupling of ERT and SP data leads to interesting hypotheses concerning their hydrogeological system structure. The eastern parts of ERT profiles "NPT-EFE" and "STA-EFE" exhibit conductive axes (CN1, CN2, CN3; Figs. 6, 7) reaching the surface. The eastern flank of l'Echelle cone and the northern part of La Citerne most probably constitute a major infiltration zone for meteoric fluids. These axes are connected to a relatively superficial massive conductive body interpreted as a major perched aquifer, common to the two edifices, and dipping south-west at depth (Fig. 7). This interpretation is consistent with SP data along the profile, and the calculation of the SPS surface more or less matching the limit of the conductive body at depth. In the central parts of the profile, variations of this limit is not well-constrained by the ERT section which is not deep enough and exhibits high DOI indexes (Appendix A). Other signs in that zone corroborate the existence of an aquifer, such as the presence of the Flammarion lake occupying the Citerne crater (Fig. 1), and the lithology of the Citerne tuff cone itself with phreato-magmatic deposits, implying the presence of an aquifer or a lake during its terminal phase.

Future hydrologic surveys might be able to determine the origin of the aquifer shape, which could be hosted in low-strength layers resulting formed by the slip surface of paleo-collapse events on an edifice that predated the formation of the L'Echelle and Citerne scoria cones or from older debris avalanche deposits from the Carmichael edifice dated at ca. 13,400 yrs B.P (Komorowski et al., 2005; Legendre, 2012).

\section{Conclusion}

This paper proposes an integrated analysis of electrical resistivity tomography, self-potential, ground thermometry and soil $\mathrm{CO}_{2}$ gas measurements on La Soufrière lava dome and its southern periphery. The coupling of these independent methods strengthens their reliability and brings further constraints on the relationships between superficial structures, hydrothermal, and magmatic fluid circulation. Results have highlighted that ascending flows are restricted to a proximal domain including the dome and its very vicinity. ERT suggests that lateral extension of the hydrothermal system, and resulting alteration, could be contained by a combination of several structural limits such as the axes of major fractures/faults and the boundaries of sector collapses surrounding the dome. Beyond these limits, the southern distal periphery shows no sign of hydrothermal circulation. Coupling of ERT and SP have revealed a complex system of perched small-volume aquifers under L'Echelle and La Citerne scoria cones.

Since $1690 \mathrm{AD}$, four of the six phreatic eruptions and most hydrothermal activity have affected the south-eastern part of the dome as well as the central summit area. Presently, the dominant ascending flux of hydrothermal and magmatic fluids is responsible for the reactivation of fumaroles on the summit area around Cratère Sud since 1992, followed by Tarissan crater. A sustained (although gradually diminishing) ascending flux of hydrothermal and magmatic fluids occurs along the surface expression of the La Ty normal fault at the south-eastern base of the dome. Shallow-depth hydrothermal fluid circulation can be further investigated using high-resolution selfpotential measurements on the dome. Significant topographic influence leads us to propose a first order correction of general SP/elevation gradient, resulting in an elevation-corrected SP showing good agreement with the observed summit hydrothermal activity. Elevation-corrected SP also highlights sub-superficial hydrothermal activity affecting the south-western border of the dome and a zone of major infiltration for meteoric fluids at the southern base. These fluids would mix with ascending hydrothermal fluids to form a ring of hot springs (Villemant et al., 2005), many of which are located along roughly the same 900-1000 $\mathrm{m}$ isocontour and relatively far away from the dome itself. These hot springs are thought to mark the fluid flow along the SW dipping listric surface of the paleo-edifice collapse structure. This structure is composed of impermeable hydrothermally altered clay-rich deposits as seen in debris avalanche deposits around the volcano (Komorowski et al., 2005; Komorowski, 2008; Salaün et al., 2011). Comparison with previous SP and ERT campaigns (Pham et al., 1990; Zlotniki et al., 1994; Nicollin et al., 2006) indicates a relative stability of the whole hydrothermal system geometry over time, but this does not exclude potential significant changes in case of a future eruption. Structural observations suggest that regional east-west extension (Feuillet, 2000; Feuillet et al., 2002) has most probably resulted in a complex system of several parallel north-south faults, which consistently correlate with the orientation of major infiltration axes in the southern distal domain of the dome. Extension of these structural lineaments and pressurization of pore-fluids along these structures might trigger future explosive phreatic activity. They also might favor partial flank failure of the dome already highly fractured to the south-east, and lying on top of a thick layer of highly altered rock saturated in fluids where friction and pore-fluid pressure might exceed the threshold of mechanical stability. A future unrest associated to a large surface deformation, as it was observed in the south-eastern region of the dome during the 1976-77 stillborn magmatic eruption (Feuillard et al., 1983; Komorowski et al., 2005; Villemant et al., 2005; Boichu et al., 2011), could easily generate such flank instability.

\section{Acknowledgments}

We thank the OVSG team for the logistical support. The ERT cable and electrodes were gracefully provided by Dominique Gibert, from Géosciences Rennes. The initial DEM was obtained in 2006 using satellite Ikonos images purchased from @ C GEOEYE (processed by F. Pelaud, Latitude Geosystems) with the ACI Antilles programme of INSU. It was recently expanded and improved with Litto3D data, acquired in the context of a partnership between the French state, Shom, IGN and Agence des Aires Marines Protégées, and co-financed by the European Union. This work was supported by the Agence Nationale de la Recherche under contract ANR-08-RISKNAT-00 (DOMOSCAN). The recent eruptive history of the volcano and scenarios of possible activity have been improved in the framework of the CASAVA project of Agence Nationale de la Recherche (ANR-09-RISK-02). We acknowledge François Beauducel (IPGP) for sampling, Joël Cellier and Jean-Luc Devidal (UBP) for XRD analyses of the samples, and André Revil (Colorado School of Mines) for advice. Finally, we thank the two anonymous reviewers for their helpful comments to improve this manuscript. This is IPGP contribution no. 3525.

\section{Appendix A. ERT data processing}

The reliability of final resistivity distribution models is first dependent on the quality of the data. To avoid data noise, three types of tests were carried out before the acquisition in the field, including the continuity of the cable, its insulation, and the contact between the ground and the electrodes. When needed, the contact was improved by the addition of salty water and bentonite. 


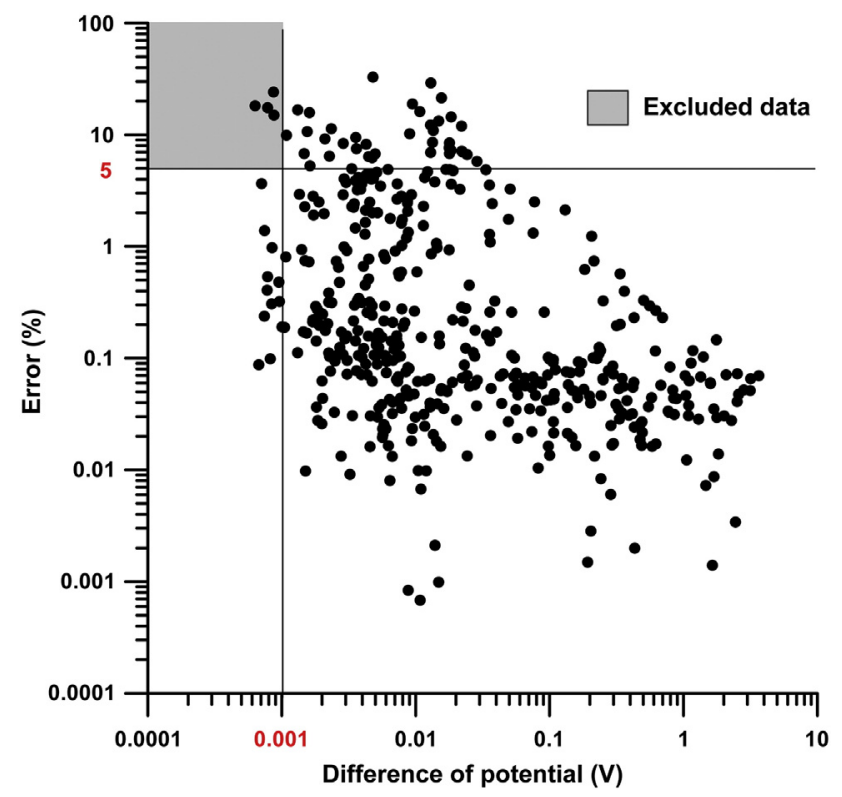

Fig. A.1. Distribution of the ERT data from "SAM-CDE" profile in a graph of the measured difference of potential versus the stacking error. The two filtering criterions are indicated in red. (For interpretation of the references to color in this figure legend, the reader is referred to the web version of this article.)
Every apparent resistivity corresponds to the mean value of five measurements (stacking). A data error estimate, calculated from the standard deviation of these measurements can be used for further data filtering. On the one hand, a manual filter was applied in order to remove the data characterized by a low signal to noise ratio. Excluding criterions are a measured electrical potential difference inferior to $1 \mathrm{mV}$ and an error superior to $5 \%$ of the value (Fig. A.1). Few points were excluded, corresponding to $0.6 \%$ of the data set for ERT profile "SAM-CDE", $0.3 \%$ for the profile "NTP-EFE" and less than $0.1 \%$ for the profile "EFE-STA". The remaining random noise can be taken into account during data inversion.

Before the inversion though, a second filter was applied using X2IPI software. Indeed, the presence of strong heterogeneities in the shallow levels generates artifacts in the measured signal. These artifacts are responsible for inclined anomalies named "C-effect", in the case of a Wenner array, and hide smoother effects linked to large and deep objects. They were removed in order to recover clearer 2D responses linked to deep and large heterogeneities (Fig. A.2).

Data inversion was performed with RES2DINV (Loke and Barker, 1996) which uses the smoothness-constrained method (Constable et al., 1987) to perform the inverse problem:

$\left(\mathbf{J}^{T} \mathbf{J}+\alpha \mathrm{F}\right) \mathbf{d}=\mathbf{J}^{T} \mathrm{~g}-\alpha \mathrm{Fr}$

F is a smoothing matrix, $\mathbf{J}$ is the Jacobian matrix of partial derivatives, $\mathbf{r}$ is a vector containing the logarithm of the model resistivity value, $\alpha$ is the damping factor, $\mathbf{d}$ is the model perturbation vector, and $\mathbf{g}$ the discrepancy vector (i.e. the differences between observed data and the
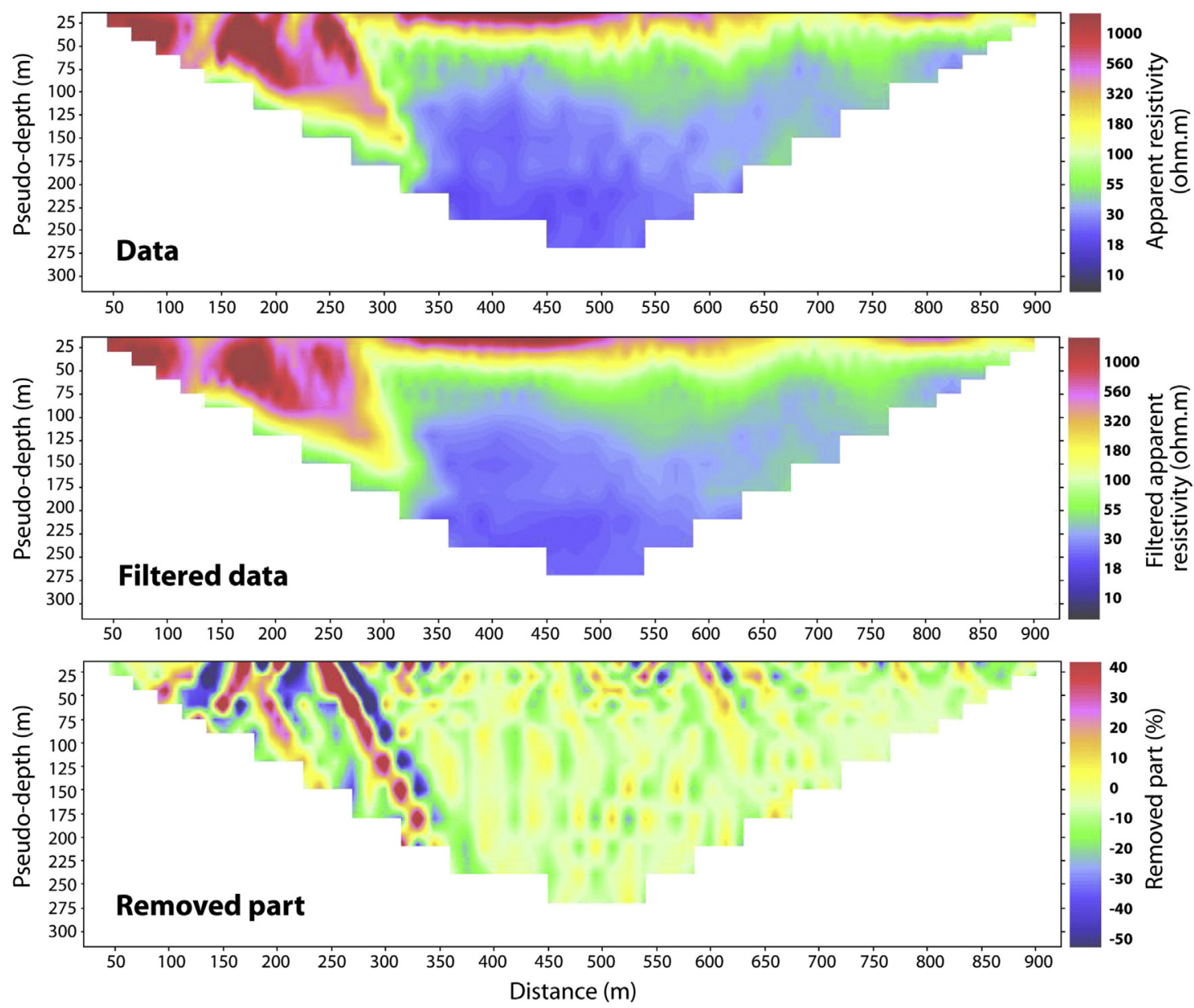

Fig. A.2. Effect of data filtering under X2IPI in profile "SAM-CDE". The removed part of the signal corresponds to artifacts related to the surface resistivity contrasts. 
model response). The magnitude of this vector is given by a root-mean squared value (RMS). The algorithm starts from an initial model (reference model) and seeks to reduce this quantity to find a better model after every iteration.

Data noise estimates may be included in the inversion process. In this case, the least squares equation (A.1) is modified to the following one:

$$
\left(\mathbf{J}^{T} \mathbf{W}_{\mathrm{d}}^{T} \mathbf{W}_{\mathrm{d}} \mathbf{J}+\alpha \mathrm{F}\right) \mathbf{d}=\mathbf{J}^{T} \mathbf{W}_{\mathrm{d}}^{T} \mathbf{W}_{\mathrm{d}} \mathrm{g}-\alpha \mathrm{Fr}
$$

$\mathbf{W}_{\mathrm{d}}$ is a diagonal weighting matrix incorporating the effect of data errors: data points with smaller errors are given a greater weight in the inversion process.
Non-uniqueness of the solution is an inherent problem of ERT. For the same data set, there are several possible resistivity models that fit the data equally well. The use of a smoothness constraint and a limited number of iterations (inferior 5) conform to the commonly accepted principle which states that simpler models must be preferred to more complex ones to explain a given data set. At iteration 5, profiles "SAMCDE", "NPT-EFE" and "EFE-STA" exhibit respective RMS values of $14.9 \%, 16.5 \%$ and $10.0 \%$ (Fig. A.3) attesting that models responses are in good conformity with acquired data sets.

A study of the depth of investigation (DOI) was carried out by the method proposed by Oldenburg and Li (1999) and Marescot and Loke (2003). This method is based on the comparison of models calculated from two different values of the reference resistivity (defining the initial model ), $\mathrm{q}_{\mathrm{A}}$ and $\mathrm{q}_{\mathrm{B}}$. In our case, $\mathrm{q}_{\mathrm{A}}$ and $\mathrm{q}_{\mathrm{B}}$ correspond to $10 \mathrm{q}_{\mathrm{o}}$ and $0.1 \mathrm{q}_{\mathrm{O}}$, where $\mathrm{q}_{0}$ designates the reference resistivity used for the original
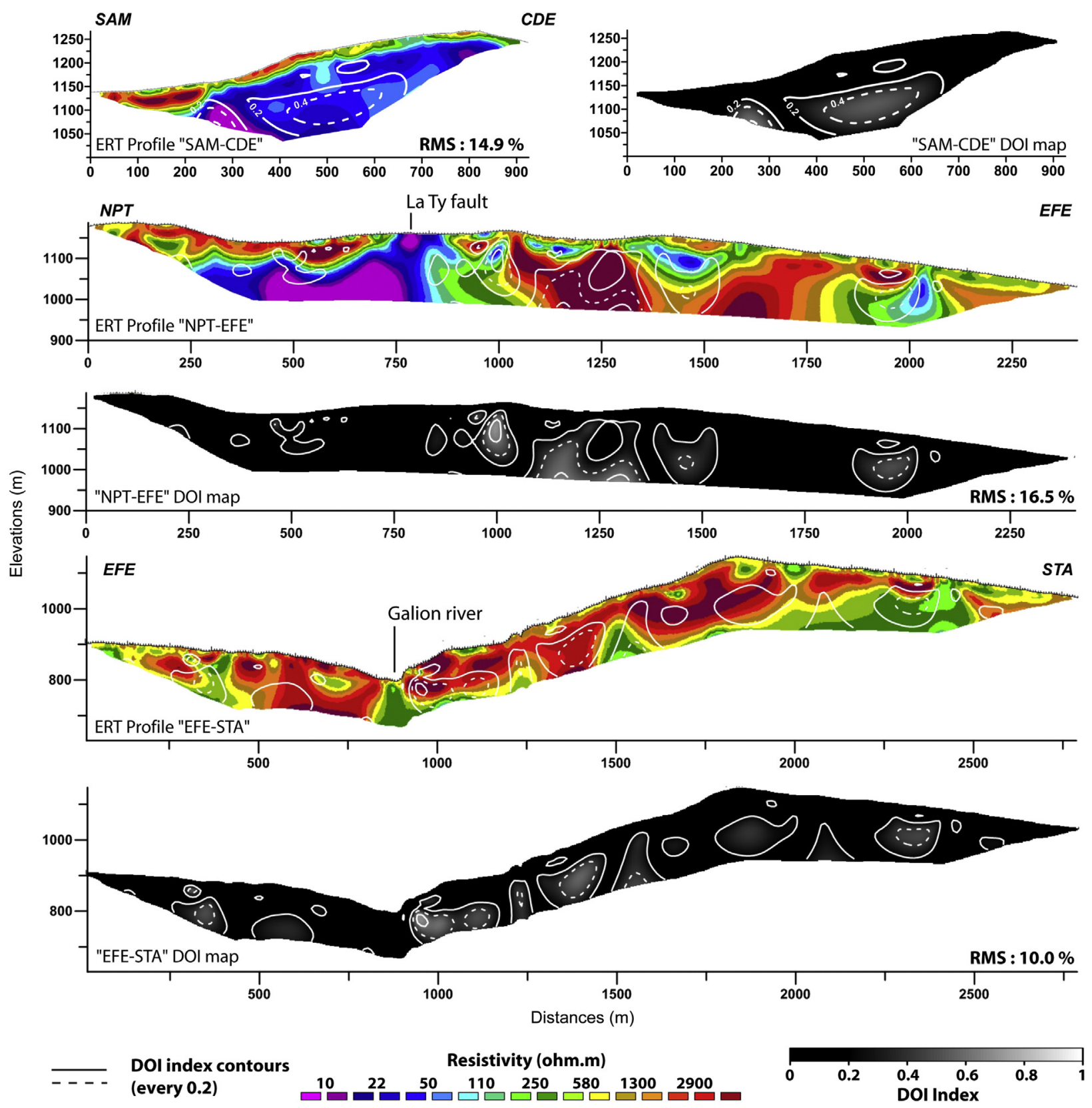

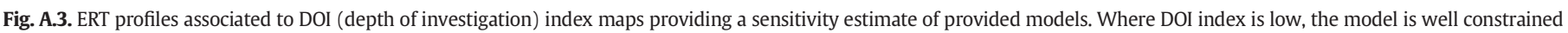
(high sensitivity). 
inversion of the data set. The DOI index value for a model cell is given by:

$R_{A B}(x, z)=\frac{q_{A}(x, z)-q_{B}(x, z)}{q_{A}-q_{B}}$

$\mathrm{q}_{\mathrm{A}}(\mathrm{x}, \mathrm{z})$ and $\mathrm{q}_{\mathrm{B}}(\mathrm{x}, \mathrm{z})$ are the values of resistivity obtained in the cell after 3 iterations of the inversion process. In areas where the DOI index approaches zero, the two inversions give the same resistivity values, meaning that the model is well constrained by the data set (good sensitivity). In areas where the index approaches unity, the model is not constrained by the data (poor sensitivity). In the case of "SAM-CDE" ERT profile (Fig. A.3), the model can be trusted until $100 \mathrm{~m}$ below the surface approximately (index $<0.3$ ). For the "EFE-NPT" profile, sensibility is good in the western part corresponding to the dome base and La Ty areas, in spite of strong resistivity contrasts (Figs. 6, A.3). Resistive structures in its central part (corresponding to L'Echelle edifice) are not well constrained. On profile "EFE-STA", sensibility is good except in the very central part of the profile, to the east of the Galion river bed, from 100 m-deep.

\section{Appendix B. SPS surface calculation}

In areas exhibiting a high ratio between the resistivities of the unsaturated zone and the water-saturated zone, and in the case of an homogeneous unsaturated zone, Aubert and Atangana (1996) argue that a linear correlation exists between the range of negative SP anomalies and the thickness of the unsaturated zone. They introduce the notion of SPS surface, the equipotential SP surface corresponding to the interface between the unsaturated zone and the saturated medium. The altitude $\mathrm{H}(\mathrm{m})$ of the SPS surface is calculated from the following equation:

$H(x, y)=h(x, y)-\frac{V(x, y)-V^{\circ}}{L}-E^{\circ}$

$V(x, y)$ and $h(x, y)$ are the values of self-potential $(\mathrm{mV})$ and altitude (m) at the station $(x, y)$, and $V^{\circ}$ and $E^{\circ}$ are the self-potential and thickness of the unsaturated zone at the reference station. According to Aubert and Atangana (1996), the coefficient $L$, generally comprised between -1 and $-10 \mathrm{mV} / \mathrm{m}$, depends on the resistivity and the type of porosity of the unsaturated zone, and on the resistivity ratio between unsaturated and saturated zones. $L$ is not known a priori, but may be calculated from piezometric surfaces in boreholes for example.

SPS surface calculation was applied to profiles "SAM-CDE" and "EFESTA" (portion to the east of the Galion River) considering firstly that the medium constituting the unsaturated zone is more or less homogeneous in both cases, and that SP signal is not disturbed by major vertical fluid flows along these profiles. Such approximations cannot reasonably apply to the case of the "NPT-EFE" profile. Qualitatively, SPS surface variations resemble the variations of strong resistivity contrasts evidenced in the ERT sections. With $\mathrm{L}$ coefficients of $-3 \mathrm{mV} / \mathrm{m}$ and $-1.5 \mathrm{mV} / \mathrm{m}$, a good match is obtained (Figs. 5, 7) for "SAM-CDE" and "EFE-STA" profiles, respectively. These resistivity contrasts may then be considered as upper limits of the water-saturated zone along these two profiles. The difference in L coefficient can be attributed to the differences in permeabilities and resistivity contrasts inside La Soufrière dome and La Citerne edifice.

\section{References}

Aizawa, K., 2008. Classification of self-potential anomalies on volcanoes and possible interpretations for their subsurface structure. J. Volcanol. Geotherm. Res. 175, 253-268. http://dx.doi.org/10.1016/j.jvolgeores.2008.03.011.

Aizawa, K., Uyeshima, M., Nogami, K., 2008. Zeta potential estimation of volcanic rocks on 11 island arc-type volcanoes in Japan: implication for the generation of local selfpotential anomalies. J. Geophys. Res. 113, B02201. http://dx.doi.org/10.1029/ 2007JB005058.
Allard, P., Aiuppa, A., Beauducel, F., Gaudin, D., Di Napoli, R., Calabrese, S., Parello, F., Crispi, O., Hammouya, G., Tamburello, G., 2014. Steam and gas emission rate from La Soufriere volcano, Guadeloupe (Lesser Antilles): implications for the magmatic supply during degassing unrest. Chem. Geol. 384, 76-93. http://dx.doi.org/10.1016/j. chemgeo.2014.06.019.

Aubert, M., Atangana, Q., 1996. Self-potential method in hydrogeological exploration of volcanic areas. Ground Water 34 (6), 1010-1016.

Aubert, M., Antraygues, P., Soler, E., 1993. Interpretation of the self-potential measurements in hydrogeological exploration of a volcanic massif. On the existence of groundwater flow paths on the south flank of the Piton de la Fournaise (Reunion Island). Bull. Soc. Geol. Fr. 164 (1), 17-25.

Barde-Cabusson, S., Bolós, X., Pedrazzi, D., Lovera, R., Serra, G., Martí, J., Casas, A., 2013. Electrical resistivity tomography revealing the internal structure of monogenetic volcanoes. Geophys. Res. Lett. 40, 2544-2549. http://dx.doi.org/10.1002/grl. 50538.

Bigot, S., Boudon, G., Semet, M.P., Hammouya, G., 1994. Traçage chimique de la circultation des eaux souterraines sur le volcan de la Grande Découverte (La Soufrière), Guadeloupe. C. R. Acad. Sci. 319 (10), 1215-1221.

Boichu, M., Villemant, B., Boudon, G., 2008. A model for episodic degassing of an andesitic magma intrusion. J. Geophys. Res. 113, B07202.

Boichu, M., Villemant, B., Boudon, G., 2011. Degassing at La Soufrière de Guadeloupe volcano (Lesser Antilles) since the last eruptive crisis in 1975-77: result of a shallow magma intrusion? J. Volcanol. Geotherm. Res. 203 (3-4), 102-112.

Boudon, G., Dagain, J., Semet, M., Westercamp, D., 1988. Carte et notice explicative de la carte géologique du massif volcanique de la Soufriere (Département de la Guadeloupe, Petites Antilles), scale 1: 20,000, Bur. de Rech. Geol. et Min., Orléans, France.

Boudon, G., Semet, M., Vincent, P., 1992. Les Eruptions a ecroulement de flanc sur le volcan de la Grande-Decouverte (La Soufriere) de Guadeloupe; implications sur le risque volcanique. Bull. Soc. Geol. Fr. 163 (2), 159-167.

Boudon, G., Le Friant, A., Komorowski, J.-C., Deplus, C., Semet, M.P., 2007. Volcano flank instability in the Lesser Antilles Arc: diversity of scale, processes, and temporal recurrence. J. Geophys. Res. 112, B08205.

Boudon, G., Komorowski, J.-C., Villemant, B., Semet, M.P., 2008. A new scenario for the last magmatic eruption of La Soufrière of Guadeloupe (Lesser Antilles) in 1530 A.D. Evidence from stratigraphy radiocarbon dating and magmatic evolution of erupted products. J. Volcanol. Geotherm. Res. 178, 474-490.

Byrdina, S., Revil, A., Pant, S.R., Koirala, B.P., Shrestha, P.L., Tiwari, D.R., Gautam, U.P., Shrestha, K., Sapkota, S.N., Contraires, S., Perrier, F., 2009. Dipolar self-potential anomaly associated with carbon dioxide and radon flux at Syabru-Bensi hot springs in central Nepal. J. Geophys. Res. 114, B10101. http://dx.doi.org/10.1029/2008JB006154.

Byrdina, S., Ramos, D., Vandemeulebrouck, J., Masias, P., Revil, A., Finizola, A., Gonzales Zuñiga, K., Cruz, V., Antayhua, Y., Macedo, O., 2013. Influence of the regional topography on the remote emplacement of hydrothermal systems with examples of Ticsani and Ubinas volcanoes, Southern Peru. Earth Planet. Sci. Lett. 365, 152-164. http://dx doi.org/10.1016/j.epsl.2013.01.018.

Carlut, J., Quidelleur, X., Courtillot, V., Boudon, G., 2000. Paleomagnetic directions and K/Ar dating of 0-1 Ma lava flows from La Guadeloupe Island (French WestIndies): implications for time averaged field models. J. Geophys. Res. 105, 835-849.

Chen, J.-B., Gaillardet, J., Dessert, C., Villemant, B., Louvat, P., Crispi, O., Birck, J.-L., Wang, Y.N., 2014. Zn isotope compositions of the thermal spring waters of La Soufrière volcano, Guadeloupe Island. Geochim. Cosmochim. Acta 127, 67-82. http://dx.doi.org/10. 1016/j.gca.2013.11.022

Chiodini, G., Cioni, R., Guidi, M., Raco, B., Marini, L., 1998. Soil $\mathrm{CO}_{2}$ flux measurements in volcanic and geothermal areas. Appl. Geochem. 13 (5), 543-552.

Chorom, M., Rengasamy, P., 1995. Dispersion and zeta potential of pure clays as related to net particle charge under varying $\mathrm{pH}$, electrolyte concentration and cation type. Eur. J. Soil Sci. 46, 657-665. http://dx.doi.org/10.1111/j.1365-2389.1995. tb01362.x.

Constable, S.C., Parker, R.L., Constable, C.G., 1987. Occam's inversion: a practical algorithm for generating smooth models from electromagnetic sounding data. Geophysics 52, 289-300. http://dx.doi.org/10.1190/1.1442303.

Corwin, R.F., Hoover, D.B., 1979. The self-potential method in geothermal exploration. Geophysics 44 (2), 226-245.

Coutant, O., Bernard, M.L., Beauducel, F. Nicollin, F., Bouin, M.P. Roussel, S., 2012. Joint inversion of P-wave velocity and density, application to La Soufrière of Guadeloupe hydrothermal system. Geophys. J. Int. 191, 723-742.

David, J., 1998. Synthèse des mesures de déformation à la soufrière de guadeloupe, 1976-1996: contribution à l'étude du fonctionnement du volcan(PhD thesis) Institut de Physique du Globe de Paris, (433 pp.).

Feuillard, M., 1976. Etudes thermiques à la Soufrière de la Guadeloupe. Bulletin du BRGM (2ième serie) 4, 375-388 (section IV).

Feuillard, M., 2011. La Soufrière de Guadeloupe: un volcan et un peuple, Jasor, Pointe-àPitre, edition Jasor. pp. 1-246.

Feuillard, M., Allegre, C., Brandeis, G., 1983. The 1975-1977 crisis of La Soufriere de Guadeloupe (FWI): a still-born magmatic eruption. J. Volcanol. Geotherm. Res. 16, 317-334.

Feuillet, N., 2000. Sismotectonique des Petites Antilles, liaison entre activité sismique et volcanique( $\mathrm{PhD}$ thesis) Univ. Paris 7 René Diderot.

Feuillet, N., Manighetti, I., Tapponnier, P., Jacques, E., 2002. Arc parallel extension and localization of volcanic complexes in Guadeloupe, Lesser Antilles. J. Geophys. Res. 107 (B12), 2331.

Finizola, A., Sortino, F., Lénat, J.-F., Valenza, M., 2002. Fluid circulation at Stromboli volcano (Aeolian Islands, Italy) from self-potential and soil gas surveys. J. Volcanol. Geotherm. Res. 116 (1-2), 1-18

Finizola, A., Sortino, F., Lénat, J.-F., Aubert, M., Ripepe, M., Valenza, M., 2003. The summit hydrothermal system of Stromboli. New insights from self-potential, temperature, 
$\mathrm{CO}_{2}$ and fumarolic fluid measurements, with structural and monitoring implications. Bull. Volcanol. 65 (7), 486-504

Finizola, A., Lénat, J.-F., Macedo, O., Ramos, D., Thouret, J.-C., Sortino, F., 2004. Fluid circulation and structural discontinuities inside Misti volcano (Peru) inferred from selfpotential measurements. J. Volcanol. Geotherm. Res. 135-4, 343-360. http://dx.doi. org/10.1016/j.jvolgeores.2004.03.009.

Finizola, A., Revil, A., Rizzo, E., Piscitelli, S., Ricci, T., Morin, J., Angeletti, B., Mocochain, L., Sortino, F., 2006. Hydrogeological insights at Stromboli volcano (Italy) from geoelectrical, temperature, and CO 2 soil degassing investigations. Geophys. Res. Lett. 33, L17304. http://dx.doi.org/10.1029/2006GL026842.

Finizola, A., Aubert, M., Revil, A., Schütze, C., Sortino, F., 2009. Importance of structural history in the summit area of Stromboli during the 2002-2003 eruptive crisis inferred from temperature, soil $\mathrm{CO}_{2}$, self-potential, and electrical resistivity tomography. J. Volcanol. Geotherm. Res. 183 (3), 213-227.

Fournier, C., 1983. Méthodes géoélectriques appliquées à l'hydrogéologie en région volcanique (Chaîne des Puys, Massif Central français). Développement de la méthode des potentiels spontanés en hydrogéologie. Univ. Montpellier, (PhD thesis).

Gailler, L.-S., Martelet, G., Thinon, I., Bouchot, V., Lebrun, J.F., Münch, P., 2013. Crustal structure of Guadeloupe Islands and the Lesser Antilles Arc from a new gravity and magnetic synthesis. Bull. Soc. Geol. Fr. 184 (1-2), 77-97.

Gaudin, D., Beauducel, F., Allemand, P., Delacourt, C., Finizola, A., 2013. Heat flux measurement from thermal infrared imagery in low-flux fumarolian zone: example of the Ty fault (La Soufrière de Guadeloupe). J. Volcanol. Geotherm. Res. 267 47-56.

Guichet, X., Jouniaux, L., Catel, N., 2006. Modification of streaming potential by precipitation of calcite in a sand-water system: laboratory measurements in the $\mathrm{pH}$ range from 4 to 12. Geophys. J. Int. 166, 445-460. http://dx.doi.org/10.1111/j.1365-246X. 2006.02922.x.

Gunawan, H., 2005. Gravimétrie et microgravimétrie appliquées à la volcanologie: exemples de la Soufrière de Guadeloupe et du Mérapi(PhD thesis) Institut de Physique du Globe de Paris, (202 pp.).

Hincks, T.K., Komorowski, J.-C., Sparks, S.R., Aspinall, W.P., 2014. Retrospective analysis of uncertain eruption precursors at La Soufrière volcano, Guadeloupe, 1975-77: volcanic hazard assessment using a Bayesian Belief Network approach. J. Appl. Volcanol. 3, 3. http://dx.doi.org/10.1186/2191-5040-3-3.

Hussain, S.A., Demirci, S., Özbayoglu, G., 1996. Zeta Potential Measurements on Three Clays from Turkey and Effects of Clays on Coal Flotation. J. Colloid Interface Sci. 184, 535-541.

Ishido, T., 2004. Electrokinetic mechanism for the "W"-shaped self-potential profile on volcanoes. Geophys. Res. Lett. 31 (15), L15616.

Jackson, D.B., Kauahikaua, J., 1987. Regional self-potential anomalies at Kilauea volcano. Volcanism in Hawaii. USGS Professional paper vol. 1350, pp. 947-959 (Chap 40).

Jouniaux, L., Maineult, A., Naudet, V., Pessel, M., Sailhac, P., 2009. Review of self-potentia methods in hydrogeophysics. Compt. Rendus Geosci. 341, 928-936. http://dx.doi.org/ 10.1016/j.crte.2009.08.008

Komorowski, J.-C., 2008. Du volcan au pyroclaste : une approche pluridisciplinaire de la compréhension des processus éruptifs et de l'évaluation des aléas. Habilitation à Diriger des Recherches. Université Paris 7 René Diderot, (549 pp.).

Komorowski, J.-C., Boudon, G., Antenor-Habazac, C., Hammouya, G., Semet, M., David, J Beauducel, F., Cheminée, J.-L., Feuillard, M., 2001. L'activité éruptive et non-éruptive de la Soufrière de Guadeloupe: problèmes et implications de la phénoménologie et des signaux actuellement enregistrés. INSU Lesser Antilles Volcanic Hazard Workshop, Paris, pp. 18-19 (abstract volume).

Komorowski, J.-C., Boudon, G., Semet, M., Villemant, B., Hammouya, G., 2002. Recurrent flank-collapses at Soufrière of Guadeloupe volcano: implications of acid hydrothermal fluids on edifice stability Mount Pelée 1902-2002; Explosive volcanism in subduction zones. IPGP-INSU-IAVCEI International Congress, Martinique, p. 69 (abstract volume).

Komorowski, J.-C., Boudon, G., Semet, M., Beauducel, F., Anténor-Habazac, C., Bazin, S. Hammouya, G., 2005. Guadeloupe. In: Lindsay, J.M., Robertson, R.E.A., Sheperd, J.B. Ali, S. (Eds.), Volcanic Altas of the Lesser Antilles. Seismic Res.Unit. The University of the West Indies, Trinidad and Tobago, West Indies, pp. 65-102.

Komorowski, J-C. Boudon, G, Le Friant, A, Legendre, Y., 2008a. A remarkable Holocen record of flank-collapses at La Soufrière volcano (Guadeloupe): implications for future hazards and scenarios. Paper presented at the International Association of Volcanology and Chemistry of the Earth's Interior (IAVCEI). General Assembly, Reijkavik, Iceland, pp. 17-23.

Komorowski, J.-C., Legendre, Y., Caron, B., Boudon, G., 2008b. Reconstruction and analysis of sub-Plinian tephra dispersal during the 1530 A.D. Soufrière (Guadeloupe) eruption: implications for scenario definition and hazards assessment. J. Volcanol. Geotherm. Res. 178, 491-515.

Legendre, Y., 2012. Reconstruction fine de l'histoire éruptive et scénarii éruptifs à la Soufrière de Guadeloupe: vers un modèle intégré de fonctionnement du volcan(PhD thesis) Univ. Paris 7 René Diderot.

Lesparre, N., Gibert, D., Marteau, J., Komorowski, J.-C., Nicollin, F., Coutant, O., 2012. Density muon radiography of La Soufrière of Guadeloupe volcano: comparison with geological, electrical resistivity and gravity data. Geophys. J. Int. 190, 1008-1019.

Lesparre, N., Grychtol, B., Gibert, D., Komorowski, J.-C., Adler, A., 2014. Cross-section electrical resistance tomography of La Soufrière of Guadeloupe lava dome. Geophys. J. Int. $197,1516-1526$

Li, L., Jendrzejewski, N., Aubaud, C., Bonifacie, M., Crispi, O., Dessert, C., Agrinier, P., 2012. Isotopic evidence for quick freshening of magmatic chlorine in the Lesser Antilles arc volcanoes. Abstract presented at AGU Fall Meeting, 3-5, December 2012, San Francisco, USA. 980 V53B-2831.
Loke, M.H., Barker, R.D., 1996. Rapid least-squares inversion of apparent resistivity pseudosections by a quasi-Newton method. Geophys. Prospect. 44 (1), 131-152.

López, D.L., Williams, S.N., 1993. Catastrophic volcanic collapse: relation to hydrothermal processes. Science 260, 1794-1796.

Lube, G., Breard, E.C.P., Cronin, S.J., Procter, J.N., Brenna, M., Moebis, A., Pardo, N., Stewart, R.B., Jolly, A., Fournier, N., 2014. Dynamics of surges generated by hydrothermal blasts during the 6 August 2012 Te Maari eruption, Mt. Tongariro, New Zealand. J. Volcanol. Geotherm. Res. http://dx.doi.org/10.1016/j.jvolgeores.2014.05.010 (in press).

Marescot, L., Loke, M., 2003. Assessing reliability of 2D resistivity imaging in mountain permafrost studies using the depth of investigation index method. Near Surf. Geophys. 1, 57-67.

Mathieu, L., van Wyk de Vries, B., Mannessiez, C., Mazzoni, N., Savry, C., Troll, V.R., 2013. The structure and morphology of the Basse Terre Island, Lesser Antilles volcanic arc. Bull. Volcanol. 75 (3), 1-15.

Nicollin, F., Gibert, D., Beauducel, F., Boudon, G., Komorowski, J.-C., 2006. Electrical tomography of La Soufrière of Guadeloupe Volcano: field experiments, 1D inversion and qualitative interpretation. Earth Planet. Sci. Lett. 244, 709-724.

Observatoire Volcanologique et Sismologique de la Guadeloupe (OVSG-IPGP), 1999-2014. Bilan Mensuel de l'Activité Volcanique de la Soufrière et de la Sismicité régionale, Observatoire Volcanologique et Sismologique de la Guadeloupe. Institut de Physique du Globe de Paris, IPGP-CNRS-INSU Conseil Général de Guadeloupe, (published online at: http://www.ipgp.jussieu.fr/pages/0303040901.php).

Oldenburg, D.W., Li, Y., 1999. Estimating depth of investigation in dc resistivity and IP surveys. Geophysics $64,403-416$

Petrillo, Z., Chiodini, G., Mangiacapra, A., Caliro, S., Capuano, P., Russo, G., Cardellini, C., Avino, R., 2013. Defining a 3D physical model for the hydrothermal circulation at Campi Flegrei caldera (Italy). J. Volcanol. Geotherm. Res. 264, 172-182. http://dx. doi.org/10.1016/j.jvolgeores.2013.08.008.

Pham, V.N., Boyer, D., Boudon, G., Gruszow, S., Zlotnicki, J., 1990. Anomalies de polarisation spontanée sur la Soufrière de Guadeloupe. Relation avec la structure interne du volcan. C. R. Acad. Sci. 2 (319), 815.

Portal, A., Labazuy, P., Lénat, J.-F., Béné, S., Boivin, P., Busato, E., Cârloganu, C., Combaret, C. Dupieux, P., Fehr, F., Gay, P., Laktineh, I., Miallier, D., Mirabito, L., Niess, V., Vulpescu, B., 2013. Inner structure of the Puy de Dôme volcano: cross-comparison of geophysical models (ERT, gravimetry, muon imaging). Geosci. Instrum. Methods Data Syst. 2, 47-54. http://dx.doi.org/10.5194/gi-2-47-2013.

Reid, M.E., Sisson, T.W., Brien, D.L., 2001. Volcano collapse promoted by hydrothermal alteration and edifice shape, Mount Rainier, Washington. Geology 29, 779-782.

Revil, A., Finizola, A., Piscitelli, S., Rizzo, E., Ricci, T., Crespy, A., et al., 1978-2012. Inner structure of La Fossa di Vulcano (Vulcano Island, southern Tyrrhenian Sea, Italy) revealed by high-resolution electric resistivity tomography coupled with self-potential, temperature, and $\mathrm{CO}_{2}$ diffuse degassing measurements. J. Geophys. Res. Solid Earth 113 (B7).

Revil, A., Finizola, A., Ricci, T., Delcher, E., Peltier, A., Barde-Cabusson, S., Avard, G., Bailly, T., Bennati, L., Byrdina, S., Colonge, J., Di Gangi, F., Douillet, G., Lupi, M., Letort, J., Tsang Hin Sun, E., 2011. Hydrogeology of Stromboli volcano, Aeolian Islands (Italy) from the interpretation of resistivity tomograms, self-potential, soil temperature and soil CO2 concentration measurements. Geophys. J. Int. 186, 1078-1094. http://dx.doi. org/10.1111/j.1365-246X.2011.05112.x.

Ruzié, L., Moreira, M., Crispi, O., 2012. Noble gas isotopes in hydrothermal volcanic fluids of La Soufrière volcano, Guadeloupe, Lesser Antilles arc. Chem. Geol. 304-305, 158-165.

Ruzié, L., Aubaud, C., Moreira, M., Agrinier, P., Dessert, C., Gréau, C., Crispi, O., 2013. Carbon and helium isotopes in thermal springs of La Soufrière volcano (Guadeloupe, Lesser Antilles): implications for volcanological monitoring. Chem. Geol. 359, 70-80. http://dx.doi.org/10.1016/j.chemgeo.2013.09.008.

Saka, E.E., Güler, C., 2006. The effects of electrolyte concentration, ion species and $\mathrm{pH}$ on the zeta potential and electrokinetic charge density of montmorillonite. Clay Miner. 41, 853-861. http://dx.doi.org/10.1180/0009855064140224.

Salaün, A., Villemant, B., Gérard, M., Komorowski, J.-C., Michel, A., 2011. Hydrothermal alteration in andesitic volcanoes: trace element redistribution in active and ancient hydrothermal systems of Guadeloupe (Lesser Antilles). J. Geochem. Explor. 111, 59-83.

Samper, A., Quidelleur, X., Lahitte, P., Mollex, D., 2007. Timing of effusive volcanism and collapse eventswithin an oceanic arc island: Basse-Terre, Guadeloupe archipelago (Lesser Antilles Arc). Earth Planet. Sci. Lett. 258, 175-191.

Samper, A., Quidelleur, X., Komorowski, J.-C., Lahitte, P., Boudon, G., 2009. Effusive history of the Grande Découverte VolcanicComplex, southern Basse-Terre (Guadeloupe, French West Indies) from new K-ArCassignol-Gillotages. J. Volcanol. Geotherm. Res. $187,117-130$

Sinclair, A.J., 1974. Selection of threshold values in geochemical data using probability graphs. J. Geochem. Explor. 3 (2), 129-149.

Vallance, J.W., Scott, K.M., 1997. The Osceola Mudflow from Mount Rainier: sedimentology and hazard implications of a huge clay-rich debris flow. The Holocene 109, 143-163.

Villemant, B., Hammouya, Gilbert, Michel, A., Semet, M.P., Komorowski, J.-C., Boudon, G., Cheminée, J.-L., 2005. The memory of volcanic waters: shallow magma degassing revealed by halogen monitoring in thermal springs of La Soufrière volcano (Guadeloupe, Lesser Antilles). Earth Planet. Sci. Lett. 237, 710-728.

Yukselen, Y., Kaya, A., 2003. Zeta potential of kaolinite in the presence of alkali, alkaline earth and hydrolyzable metal ions. Water Air Soil Pollut. 145, 155-168.

Yukselen-Aksoy, Y., Kaya, A., 2010. A study of factors affecting on the zeta potential of kaolinite and quartz powder. Environ. Earth Sci. 62, 697-705. http://dx.doi.org/10.1007/ s12665-010-0556-9.

Zablocki, C.J., 1978. Streaming potentials resulting from the descent of meteoric water: a possible source mechanism for Kilauean self-potential anomalies. Geothermal 
energy: a novelty becomes resource. Geotherm. Resour. Counc., Davis, Calif. United States (USA), Hilo, Hawaii, United States, pp. 747-748.

Zlotnicki, J., Nishida, Y., 2003. Review on morphological insights of self-potential anomalies on volcanoes. Surv. Geophys. 24, 291-338.

Zlotnicki, J., Boudon, Georges, Mouel, J.-L., 1992. The volcanic activity of La Soufrière of Guadeloupe (Lesser Antilles): structural and tectonic implications. J. Volcanol. Geotherm. Res. 49, 91-104.
Zlotnicki, J., Vargemezis, G., Mille, A., Bruère, F., Hammouya, G., 2006. State of the hydrothermal activity of Soufrière of Guadeloupe volcano inferred by VLF surveys. J. Appl. Geophys. 58, 265-279. http://dx.doi.org/10.1016/j.jappgeo.2005.05.004.

Zlotniki, J., Feuillard, M., Hammouya, G., 1994. Water circulations on La Soufrière volcano inferred by self-potential surveys (Guadeloupe, Lesser Antilles). Renew of volcanic activity? J. Geomagn. Geoelectr. 46, 79778-79813. 